\title{
Peace Is in the Eye of the Beholder: How Perceptions of Impartiality Shape Peacekeeping Outcomes
}

\author{
William G. Nomikos*
}

July 30, 2021

\begin{abstract}
Despite abundant evidence that UN peacekeepers limit armed group violence during and after civil wars, we know relatively little about their ability to contain more localized forms of violence between non-state actors. Given the recent rise in atrocities and mass displacements due to communal violence across the African continent, evaluating the effectiveness of peacekeeping at this level is a pressing concern. This article demonstrates that peacekeeping troops prevent the onset of communal violence. I use data from a survey experiment conducted in Mali to show that the likely explanation for the effectiveness of UN peacekeepers is that locals see them as impartial. I discuss the implications for understanding the effectiveness of UN peacekeepers from different cultural backgrounds. The paper concludes that UN peacekeepers may limit the outbreak of communal violence even in the most challenging settings.
\end{abstract}

Word Count: 10,685 words

Key words: UN peacekeeping, peacebuilding, ethnic conflict, communal conflict, impartiality, Mali

*Assistant Professor, Department of Political Science, Washington University in St. Louis. Thanks to Deniz Aksoy, Kate Baldwin, Vincenzo Bove, Fotini Christia, Alex Debs, Mike Gilligan, David Carter, Carly Wayne, Keith Schnakenberg, Christopher Lucas, Rob Williams, Lise Howard, David Lake, Susan Hyde, Aila Matanock, Andy Kydd, Andrea Ruggeri, Nicholas Sambanis, Ken Schultz, and the participants of the 2021 Weidenbaum Center Workshop on Conflict Resolution for comments. 


\section{Introduction}

How does the presence of international actors affect communal violence between non-state actors in fragile settings? Given that communal disputes over local issues such as land use, cattle herding, and access to resources are a critical source of instability in contemporary politics, it is vital to understand how international actors can help resolve them (Boone 2014; Krause 2018; Carter and Straus 2019). Limiting the outbreak of communal violence is an integral aspect of the UN's "Protection of Civilians" mandate adopted in November 2019 (Hultman, Kathman and Shannon 2020). Moreover, the Security Council mandates of all four of the UN's remaining multidimensional peacekeeping operations ${ }^{1}$ in sub-Saharan Africa - in the Democratic Republic of Congo (MONUSCO), South Sudan (UNMISS), Central African Republic (MINUSCA), and Mali (MINUSMA) - include the objective to reduce and prevent communal conflicts. $^{2}$

Although communal violence is central to these recent UN peacekeeping operations, few empirical studies have examined the ability of international interventions to resolve such violence. Prominent scholarship on UN peacekeeping has centered predominantly on the top-down effects of missions to address violence by organized armed groups (Autesserre 2010; Walter, Howard and Fortna 2019). Previous studies have shown that UN peacekeeping operations are an exceptionally potent tool for ending civil war violence (Doyle and Sambanis 2006; Fortna 2008; Howard 2008). And, though recent work has localized these findings using geocoded measures of peacekeeping deployments, the conceptual focus remains armed groups and their leadership (Ruggeri, Dorussen and Gizelis 2017; Fjelde, Hultman and Nilsson 2019;

\footnotetext{
${ }^{1}$ I use the term "peacekeeping" to refer to the conflict-reducing activities of UN military and police personnel. I use the term "multidimensional" to denote any peacekeeping operation authorized under Chapter VII of the UN Charter. These missions account for the greatest part of UN resources are the most similar to modern military interventions.

${ }^{2}$ While the UN refers to violence between civilian communities as "intercommunal," I use the term "communal violence," in keeping with the existing literature (Krause 2018; Smidt 2019). The Appendix contains the text of the most recent mandates from each of these operations.
} 
Hunnicutt and Nomikos 2020). Accounts of efforts to end civil wars focus on civilian efforts to reduce communal violence (Smidt 2019); much less is known about how UN peacekeeping troops employing coercive force directly affect intergroup relations at the individual, family, or community levels. ${ }^{3}$

This article begins to fill the gap in the literature by providing theory and causal evidence that explains when peacekeepers prevent the escalation of communal violence. My theory departs from prior studies that emphasize the UN's ability to shape formal institutions and the rule of law as a mechanism that helps local populations resolve disputes (Blair 2019, 2020a). I draw instead on rationalist accounts that emphasize the coercive capacity of peacekeepers in conflict and post-conflict settings (Doyle and Sambanis 2006; Fortna 2008; Hultman, Kathman and Shannon 2020). In contrast to other rationalist accounts, however, I focus on UN peacekeepers' efforts to stop civilian-driven communal violence rather than elite-led armed group violence. Such efforts feature prominently in policy briefs by nongovernmental organizations, government documents, and UN reports, but are almost entirely absent from political science scholarship.

In fragile settings with little or no rule of law, the physical presence of UN peacekeepers is determinative. I argue that three local-level peacekeeping practices - enforcing, apprehending, and monitoring - operate in conjunction to prevent civilians from escalating communal disputes. I identify domestic perceptions of peacekeepers' impartiality as the key source of variation in the efficacy of these practices. From the UN's inception, impartiality was meant to distinguish UN peacekeeping from other forms of military intervention. While this generally remains the case, perceptions of individual peacekeepers from different countries vary widely (Bove and Ruggeri 2019; Bove, Ruffa and Ruggeri 2020). I contend that this variation conditions their ability to peacefully resolve communal disputes.

\footnotetext{
${ }^{3}$ See Howard (2019) for a discussion of the importance of military deployments relative to civilian mission components.
} 
I test my argument by investigating peace operations in Mali, the site of large-scale communal violence managed by troops from France and the UN since 2013. I conducted an original, pre-registered experiment embedded in a survey fielded in 20 rural and peri-urban communities in Mali. The experiment presents respondents with a vignette describing a land dispute between two families from different ethnic groups and asks them if they believe violence is likely to break out. I randomly assigned some respondents to a treatment condition in which they were told a peacekeeping patrol, either from the UN or France, discovers the land dispute. The findings indicate that the peacekeepers' origins shapes respondents' beliefs about whether the dispute is likely to escalate: $19 \%$ believed that the dispute would escalate after the UN discovered it, compared to $39 \%$ for French troops and $42 \%$ if no peacekeepers find out about it - a substantively and statistically significant difference. Interviews with respondents and a mediation analysis suggest that this difference can be attributed to varying perceptions of the impartiality of the UN and France.

Following the description of the experiment and its findings, I show that the effects of perceptions of impartiality have had a meaningful impact on peacekeepers' ability to contain communal disputes. I analyze UN peacekeeping efforts using an original sub-national dataset on communal violence in Central Mali from 2013-2020. The findings indicate that, all else equal, communal violence is less likely to break out in areas with peacekeepers from Togo than those from Senegal, a difference I attribute to how Malians in the region perceive these two countries. I support the analysis with examples from qualitative accounts of peacekeeping in Mali as well as my own fieldwork in the area. These findings demonstrate that perceptions of UN impartiality are not uniform across peacekeepers. Although I highlight social identity, there may be other reasons to expect some peacekeepers to be perceived differently from others. For instance, in recent years peacekeepers from certain countries have gained a reputation for committing heinous acts of sexual exploitation and abuse. Peacekeepers from these countries are therefore unlikely to have the respect of the local population, regardless 
of how impartial they may have seemed when they first arrived.

This article extends prior research on the conditions under which the international community can help stabilize fragile settings (Beath, Christia and Enikolopov 2013; Sexton 2016; Lyall, Zhou and Imai 2020). My research shows that UN peacekeeping substantially mitigates the impact of such violence. Building on recent work unpacking the identities of UN peacekeeping operations, my study highlights ways in which some contributors to multidimensional peacekeeping operations may be more effective than others (Bove and Ruggeri 2019; Bove, Ruffa and Ruggeri 2020). These findings complement previous work that documents the efficacy of civilian-led efforts to support domestic institutions in post-conflict settings (Matanock 2017; Howard 2019; Blair, Di Salvatore and Smidt 2020; ?) and peacekeepers' well-established capacity to protect civilians from armed group violence (Fjelde, Hultman and Nilsson 2019; Hultman, Kathman and Shannon 2020).

\section{Communal Violence as a Source of Conflict}

This article focuses on communal disputes as a source of violence during and after civil war. The primary characteristic distinguishing communal violence from other forms of political violence is the absence of the state. The participants are individuals or social groups operating independently of the state with low levels of organizational complexity. Groups typically organize around a common identity, such as race, ethnicity, clan, or tribe (Sundberg, Eck and Kreutz 2012). In sub-Saharan Africa they often fight for control over land for agricultural production or cattle herding. The sources of the initial conflicts vary: traditional land boundaries may come into conflict with formal boundaries; civil wars or mass droughts may displace groups of people; or political parties or armed groups may intentionally seek to ethnicize communal disputes. Communal disputes may arise anywhere within a country, 
in rural or urban settings. ${ }^{4}$

Communal disputes precede civil wars, continue during them, and typically do not end when the wars end (Krause 2019). Communal disputes involving civilians are conceptually distinct from civil wars instigated by elite-led organizations. In practice, however, the distinction is not always as clear because the cleavages in a communal dispute may mirror those in a wider civil war. For example, the salient cleavage at the elite level in South Sudan's civil war has been between the Dinka and Nuer ethnic groups, led by Salva Kiir and Riek Machar, respectively. Yet communal disputes between these groups were not limited to the civil war. The country's communal conflicts have also frequently involved members of the Murle ethnic group as well. And violence between these communities over cattle herding rights continues despite peace agreements signed by Kiir and Machar in 2015 and 2020.

As the South Sudanese case suggests, even if local cleavages mirror those of a larger conflict, communal disputes are not initially connected to the civil war in the sense that they do not simply constitute civilians fighting on behalf of elites. Even when such disputes escalate and jeopardize a peace agreement, those civilians are not necessarily "spoilers" trying to disrupt the peace negotiations. For example, consider the "spoiling" effect of communal violence in the Democratic Republic of Congo. Such violence, localized to the eastern provinces of the country, has frequently disrupted peace agreements since the formal end of the Second Congo War in 2003 (Autesserre 2010). Yet civilians involved in disputes or clashes are not acting on behalf of elites trying to spoil a particular negotiation.

When members of a community disagree over how to settle a local issue, they face a critical decision regardless of the nature of the dispute: peacefully resolve the dispute or escalate it using one of a variety of violent means. For example, they may directly attack the other party or call upon allies associated with their family, clan, tribe, or ethnic group to do so. In conflict settings, the presence of armed militias or rebel groups presents an additional

\footnotetext{
${ }^{4}$ This definition builds on the conceptual work of Krause 2018.
} 
option - calling upon an armed group for reinforcement. The actors involved may use deadly force or a wide-ranging, non-lethal repertoire of violence, including sexual violence, torture, kidnapping, and forced displacement. ${ }^{5}$ In this way, a local dispute about an ostensibly trivial issue such as land, stolen goods, market prices, etc. can draw in groups that operate at a higher level. If they escalate in this manner, communal disputes may manifest in a variety of ways - for example as riots, communal clashes, pogroms, or massacres.

During civil wars, existing institutions often lose the capacity or legitimacy to resolve communal disputes. For instance, the conflict in 2011 that forced hundreds of thousands of members of the Guéré ethnic group living in western Côte d'Ivoire to flee their homes created pervasive communal disputes when these individuals tried to return (Balcells 2017). None of the mechanisms that sometimes resolve such conflicts were successful. The government would not (or could not) compel those who had seized Guéré land to return it. In some settings, traditional leaders have been able to address such disputes (Baldwin 2016), but victims in Côte d'Ivoire complained that the perpetrators simply ignored the traditional leaders. Civilians were unable to resolve the dispute on their own, perhaps because doing so requires exceptional social cohesion within communities or strong informal institutions for dispute resolution (Arjona 2016; Kaplan 2017). ${ }^{6}$ The pervasive communal violence that resulted from these institutional failures threatened the country's hard-fought peace. Ultimately, it was a renewed focus on resolving communal disputes within the UN peacekeeping operation deployed to Côte d'Ivoire (UNOCI) that facilitated a return to peace in Côte d'Ivoire (Smidt 2019).

Communal violence has severe consequences at multiple stages of escalation. In addition to the immediate loss of life and forced displacement, such disputes can devolve into

\footnotetext{
${ }^{5}$ Although the empirical tests emphasize lethal violence and civilian deaths, I do not claim that one set of harms is categorically worse than the other. Non-lethal violence can have long-lasting impacts over generations that may feel worse than death. See Wood 2006.

${ }^{6}$ Krause 2018 further distinguishes between three social processes of communal non-escalation: depolarization of social identities, the consolidation of civilian control, and engagement with armed groups.
} 
atrocities, lead to the formation of extremist organizations, and spark new wars. Separatists from the Tuareg ethnic group launched a rebellion in northern Mali in 2012, which spurred an intervention by France and a UN peacekeeping operation the following year. However, while the UN focused on the war in the North, communal clashes in central Mali triggered another front in the war hundreds of miles away. Islamic extremist organizations in the area, including the local al-Qaeda affiliate, exploited the disputes to attract new recruits. The resulting violence has been punctuated by massacres, sexual exploitation and assault (SEA), and the use of brutal tactics and gruesome weaponry, including machetes.

Communal disputes have represented an increasingly important aspect of civil war violence in the past 20 years. Figure 1a traces the number of civilian deaths during this period, divided by the types of civil war violence, using the Armed Conflict Location \& Event Data (ACLED) project's dataset (Raleigh et al. 2010). Whereas battlefield violence between state security forces and armed groups has more or less stayed constant, the frequency of communal violence has steadily increased. In sub-Saharan Africa, communal violence consistently kills more people than any other type of hostilities. ${ }^{7}$ Moreover, as Figure $1 \mathrm{~b}$ shows, communal violence has occurred in the majority of sub-Saharan Africa countries.

Communal clashes threaten the goals of UN peacekeeping operations, UN-brokered peace agreements, and the peacekeepers themselves (Autesserre 2010; Hunnicutt, Nomikos and Williams 2020). In recent years, the UN has therefore devoted more attention to preventing such disputes from growing violent. In the following section I discuss these efforts in greater detail, paying special attention to UN peacekeeper practices that stop the violent escalation of disputes.

\footnotetext{
${ }^{7}$ In Syria as well as some other parts of the world, armed group violence still accounts for more civilian deaths than communal violence. However, many of these deaths are attributable to the ongoing conflict in the country. Intergroup relations have become a critical issue in both Afghanistan and Iraq, both of which have previously been dominated by armed groups (Gaston and Dang 2015; Murtazashvili 2016; Mousa 2020).
} 
Figure 1: Temporal and Spatial Variation in Communal Violence, Sub-Saharan Africa, 20002020

(a) Count of violent events over time

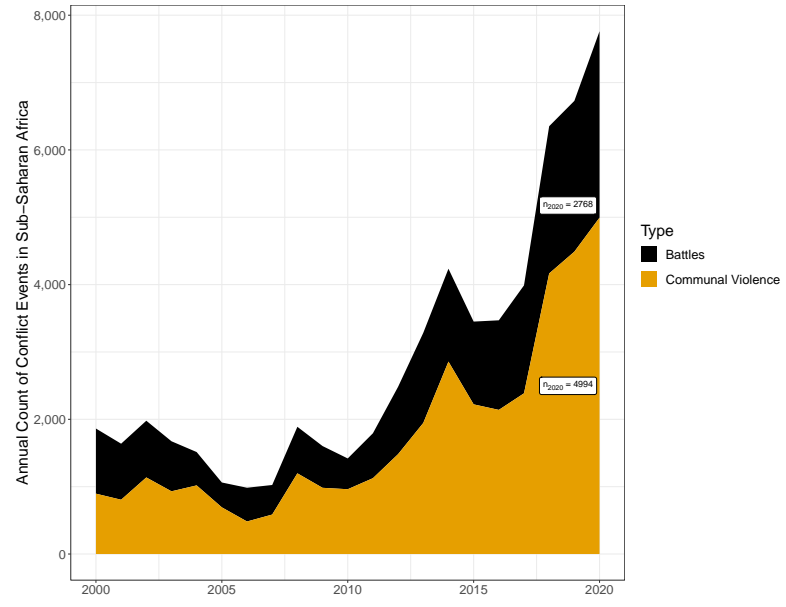

Source: ACLED. (b) Spread of violence

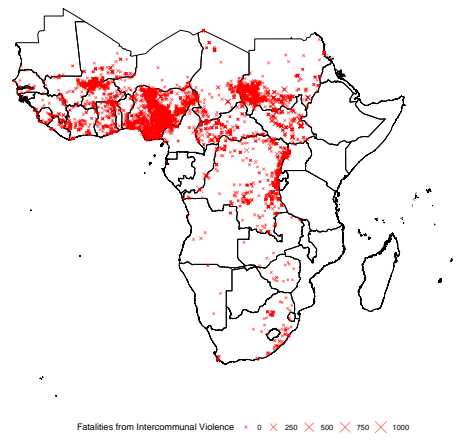

Source: ACLED.

\section{Peacekeeping Prevents the Escalation of Communal Dis-}

\section{putes}

The UN increasingly designs peacekeeping operations and their mandates based on the understanding that communal violence is a central part of the conflicts to which they will be deployed. Prior studies have discussed UN efforts to bolster conflict resolution institutions, elections, and the rule of law (Matanock 2017; Blair 2019, 2020a; Smidt 2019). Yet these practices rely on top-down institution building that may not be feasible in many settings where the UN operates. Indeed, prominent criticisms of international intervention have questioned whether such approaches produce legitimate institutions or have conflictreducing properties at all (Lake 2016). Other studies have pointed to the importance of the rapid deployment of peacekeepers from military bases as a key factor in limiting violence in conflict settings (Ruggeri, Dorussen and Gizelis 2017; Fjelde, Hultman and Nilsson 2019; Hultman, Kathman and Shannon 2020). Yet these analyses focus exclusively on the behavior 
of armed groups rather than violence emanating from communal clashes. In this section, I highlight the specific practices of UN peacekeeping that I argue prevent communal disputes from escalating into destabilizing conflicts. From there, I identify perceptions of impartiality as the key mediator of UN effectiveness. In the remainder of the article, I test the specific hypotheses derived from this analytical framework. ${ }^{8}$

\section{What Peacekeepers Do: Enforce, Apprehend, and Monitor}

When the UN Security Council approves a peacekeeping operation, UN force commanders establish a number of bases within the country of operation according to the preferences of troop-contributing countries. These bases tend to remain in place throughout the duration of the mission (Blair 2020a). Force commanders also establish temporary operating bases from which to deploy their forces to more remote locations Villa (n.d.). From these permanent and temporary bases, peacekeepers conduct weekly patrols along set routes. Although these troops rarely use coercive force, the threat of force is central to their practices. The UN estimates that more than $95 \%$ of deployed peacekeepers around the world are mandated (i.e., allowed by international law) to use any means necessary, including violence, to protect civilians from harm.

This article argues that UN peacekeepers' weekly patrols prevent individuals from escalating a dispute through three regular practices, which operate in conjunction. First, UN peacekeepers enforce peaceful cooperation between individuals. The presence of patrols increases the likelihood that any escalation of communal disputes will be punished (Howard 2019; Nomikos 2021), which is particularly important in the absence of state institutions or security forces that would otherwise do so. The Handbook for the Protection of Civilians in United Nations Peacekeeping, the UN's guide on peacekeeping tactics in the field, describes

\footnotetext{
${ }^{8}$ I pre-registered the research design with Evidence in Governance and Politics (EGAP). An anonymized version of the pre-analysis plan is included in the supplemental materials for the article. In the Appendix, I discuss all deviations from the plan.
} 
patrolling as "[entailing] credible deterrence actions or engaging in offensive operations to prevent violence against civilians" (p. 141). For example, in August 2020 a company of Bangladeshi peacekeepers from UNMISS established a temporary operating base in the rural town of Tonj in the center of South Sudan following reports of communal disputes in the area. The peacekeepers began regular patrols in the area with the explicit purpose of deterring armed group involvement (Dumo 2020; UN News 2020).

Second, UN peacekeeping patrols may also apprehend individuals and groups that might escalate a communal dispute. ${ }^{9}$ The UN describes these practices as "[apprehending] and temporarily [detaining] hostile persons or groups and, where appropriate, hand[ing] them over to the national authorities" (p. 141). The threat to apprehend, like the threat to enforce, gives peacekeepers a tool with which to shape individual behavior. Indeed, Jessica di Salvatore has shown that the mere presence of UN police who have the authority to apprehend suspects reduces criminal behavior (2019). Almost all multidimensional peacekeeping operations also authorize peacekeepers to detain individuals for a certain period of time, typically 48 hours, before handing them over to domestic authorities. For example, in April 2019, Egyptian UN police officers apprehended and detained eight individuals suspected of assaulting a convoy traveling between two small towns in central Mali. ${ }^{10}$ In some special cases, as in the Central African Republic (MINUSCA mission), UN police have had the authority to arrest criminal suspects for a longer period of time. ${ }^{11}$ For example, over the course of one year during which peacekeepers had this authority, they made 365 arrests (Howard 2019).

Finally, peacekeepers monitor ongoing disputes through their constant patrolling. They

\footnotetext{
${ }^{9}$ I use the term apprehend to distinguish from two related terms, arrest and detain. Arrest denotes a legal authority to place a suspect under criminal prosecution. Detention suggests the temporary suspension of liberty. As I describe below, the UN does not usually have the authority to arrest. However, when peacekeepers apprehend a suspect, it may lead to an arrest by state security forces so the practice is more permanent than detention alone. See (Howard 2019) for an extended discussion of these conceptual differences.

10 "Statement attributable to the Spokesman for the Secretary-General on Mali," 20 April 2019.

${ }^{11}$ In previous missions, UN police have had similar authority as part of a transitional authority mandate that is more expansive than the ones in current missions (for example, in East Timor from 1999 to 2002).
} 
gather information about potential threats from communal violence, which they can use to enforce intergroup cooperation or apprehend individuals they suspect might escalate disputes, as described above (Gordon and Young 2017; Nomikos 2021). Alternatively, peacekeepers can pass along the information to existing formal or informal authorities that may not have the resources to gather the information but are better equipped to act upon it. As the UN handbook explains, patrols "[ensure] a visible presence of UN military and police components, particularly in areas at risk where the state security forces are not present, by: assuring the population of the mission's intent to protect them from physical violence; and establishing community engagement and alert mechanisms" (p. 139). As an example of how monitoring operates in conjunction with enforcement, consider the actions of a company of Mongolian peacekeepers that set up a temporary operating base in the town of Mayom in South Sudan in February 2021 after UN force commanders learned about cattle raids in the area. Patrolling from the base, the peacekeepers monitored ongoing disputes and reacted rapidly when they thought they would escalate. For instance, after a dispute in a nearby town that they had been monitoring escalated in April 2021, peacekeepers deployed to the area within 3 hours to deter further violence.

I

Hypothesis 1 The presence of UN peacekeepers decreases the likelihood of communal violence relative to the absence of international intervention.

\section{Impartiality Conditions the Effectiveness of Local-Level Peacekeep- ing}

My primary argument is that perceptions of peacekeepers' impartiality shape the conditions under which such interventions succeed in containing communal disputes. In particular, I posit that peacekeepers are more likely to succeed in enforcing intergroup cooperation, 
apprehending suspected violent actors, and monitoring ongoing disputes the more local populations perceive them to be impartial. I argue that locals will perceive UN peacekeepers as relatively more impartial in communal disputes than international interveners from single countries, which typically become associated with former colonial occupations. As I discuss below, an important exception to this general rule is when UN peacekeepers come from troop-contributing countries that share the ethnic cleavages of the setting to which they are deployed.

I argue that locals will perceive UN peacekeepers as relatively more impartial in communal disputes than interveners from former colonial powers, regional organizations, or neighboring countries for at least three reasons. First, the UN offers individual peacekeepers a "veil" of multilateralism behind which to conduct local-level operations (Kahler 1992; Martin 1992; Bush and Prather 2018). The UN is a multilateral international organization branded in conflict and post-conflict settings as a peacemaker. Unlike former colonial powers or neighboring countries with similar ethnic cleavages, domestic populations do not associate the UN with the interests of specific ethnic, religious, or tribal groups. The second reason is that the UN is an especially diverse international organization, which can draw upon 193 sovereign member states. Moreover, the constituent forces of a given mission are constantly rotated, so that the actual composition of these forces shifts over time. Third, the UN's rules of engagement proscribe violence against civilians. When international actors harm individuals from a certain group, this causes other members of that group to believe the international actor is systematically biased against them (Lyall, Blair and Imai 2013).

Other potential interveners will likely be perceived as less impartial. Most foreign interventions are conducted by colonial powers in formerly occupied lands, where they divided their subjects to subjugate and govern them (for example, the United Kingdom in Sierra Leone or France in the Central African Republic). Locals view contemporary interventions through the prism of these past occupations, during which colonial powers favored certain 
groups over others (Tambiah 1989; Posner 2005). These perceptions extend to regional organizations such as the European Union (EU) or NATO that are dominated by Western colonial powers and perceived accordingly. Historically, smaller, less powerful countries have intervened within these organizational frameworks and become associated with colonial militarism as a result. Other major powers such as the United States consistently launch military operations in alliance with local ethnic groups, leading the wider population to associate the interveners with those groups (Sambanis, Schulhofer-Wohl and Shayo 2012). Although local populations in sub-Saharan Africa may perceive peacekeepers from neighboring regional organizations such as the African Union or the Economic Community of West African States (ECOWAS) as impartial, those organizations are made up of neighboring countries that have similar ethnic cleavages as the conflict setting, which may jeopardize their impartiality.

Even if populations do initially perceive interveners from countries or regional organizations as somewhat impartial, they will change their minds once the interveners start using offensive force. Foreign interveners have broad and expansive mandates that permit the use of violence against civilians. Moreover, they often couple ground patrols with aerial bombing campaigns or drone strikes that may hit civilians. By contrast, UN peacekeepers use violence solely in self-defense or to protect civilians. As a result, local citizens are less likely to perceive UN peacekeepers as biased against them compared to foreign interveners by virtue of their actual behavior on the ground. ${ }^{12}$

A critical exception to the view that UN peacekeepers are impartial arises when they commit acts of SEA against civilians. If this occurs, local populations start to think of peacekeepers as members of a biased out-group that is unlikely to protect them if violence erupts. The importance of civilian victimization to UN peacekeeping effectiveness, as I

\footnotetext{
${ }^{12}$ Existing research suggests that exposure to violence has no adverse effects on behavior toward members of an in-group. However, violence committed by international actors in peacekeeping operations can have adverse effects on behaviors toward an out-group (e.g., an international actor or another ethnic group). A recent review of this literature concurs with this assessment. See Bauer et al. 2016, p. 1.
} 
highlight in this article, suggests that SEA is not merely a normative concern for the UN. Indeed, the unique advantages of UN peacekeeping operations hinge on its ability to limit SEA by peacekeepers moving forward. ${ }^{13}$ Thus, the empirical predictions of this theory are premised on the assumption that the UN has largely succeeded in doing so.

Hypothesis 2 The presence of UN peacekeepers decreases the likelihood of communal violence relative to troops from other international interveners.

UN peacekeepers are not a unified entity, however. They come from a diverse array of member states, with large proportions from neighboring countries that are at least somewhat culturally proximate to peacekept populations. On the positive side, diversity offers operations complementary sets of skills, including cultural and linguistic knowledge and the ability to monitor contributors' misconduct in the field (Bove and Ruggeri 2015, 2019; Bove, Ruffa and Ruggeri 2020). However, civilians may perceive peacekeepers from some countries as more impartial than others, and this can affect peacekeepers' ability to prevent communal disputes from escalating. In particular, peacekeepers from contributing countries with similar identity cleavages to those of the peacekept population will struggle to signal their impartiality.

Hypothesis 3 The presence of UN peacekeepers from a contributing country without similar identity cleavages decreases the likelihood of communal violence relative to the presence of UN peacekeepers from a contributing country with similar identity cleavages.

Some skeptics maintain that UN impartiality is a "delusion" (Betts 1994). According to this line of thinking, when an actor invests as much human and financial capital in a post-conflict state as the UN does, it cannot maintain its impartiality (Lake 2016). The UN Security Council's bias in favor of certain armed groups might also manifest in perceptions of individual UN peacekeepers (Talentino 2007; Benson and Kathman 2014; Rhoads 2016).

\footnotetext{
${ }^{13}$ See Anderlini 2017; Karim and Beardsley 2017.
} 
Indeed, past research has demonstrated that member states use their position on the Security Council to influence where UN peacekeepers are posted (Mikulaschek 2017; Carnegie and Mikulaschek 2020). However, these theories apply to political elites and armed groups rather than citizens disputing over local issues. Interviews and survey evidence suggest that regular citizens in states with UN peacekeeping missions tend to believe the UN does too little rather than too much (Talentino 2007; Kelmendi and Radin 2016). Moreover, these critiques often conflate impartiality with neutrality (Kydd 2010). Since the UN actively intervenes to maintain order, it is not neutral in the sense of non-involvement. However, its peacekeepers apply force equally to any party or individual that disturbs the peace, and thus domestic audiences will perceive them as being relatively impartial.

The argument I present is limited in scope to conflict settings with a history of international intervention and severe ethnic fractionalization. Although many countries around the world fit these parameters, my analysis focuses on former colonial occupations of European powers in sub-Saharan Africa for three reasons. First, as Figure 1a illustrates, communal disputes are widespread in this part of the world. Second, all new UN peacekeeping operations authorized in the 21st century have been in sub-Saharan Africa, including some of the largest missions in UN history. Finally, due to the legacy of colonial occupation in these settings, local populations compare new international operations, implicitly or explicitly, to former colonial occupations.

\section{Empirical Patterns of Violence and Peacekeeping in Mali}

I test the hypotheses in Mali, a landlocked West African country with several ongoing conflicts managed by French and UN troops. At the time of research, France and several other UN troop-contributing countries had deployed patrols to prevent the escalation of communal disputes in the country. This confluence of effort offers a unique opportunity to study how 
residents of a fragile setting in which identity-based disputes are highly salient respond to peacekeeping without jeopardizing the safety and security of research participants and staff.

\section{Historical Context}

Two sets of intergroup relations chiefly characterize the socio-political context of the study. Conflict between Mali's dominant "Mandé"14 ethnic groups and the minority Tuareg ethnic groups have shaped the country's politics for decades. In addition, relations between the cattle-herding Peulh minority and primarily farming-based communities have become increasingly hostile in recent years.

After Mali achieved independence from France in 1960, the Mandé-based central government refused to grant the Tuareg their own independent state. Instead, the new government enacted policies to make Mali a purely Mandé nation-state (Jones 1972). In response, Tuareg leaders launched rebellions against the central government in 1963, 1990, 2006, and 2012 (Wing 2013). A coalition of major Tuareg armed groups signed a peace accord with the government to formally end the most recent round of hostilities in June 2015 (Pezard and Shurkin 2015). Nonetheless, relations between ethnic groups remain poor. With overextended local police services, abusive domestic military forces, and a corrupt court system, the Malian state cannot enforce the rule of law. Farmers, traders, and cattle herders instead call upon armed groups or self-defense militias to settle local scores and resolve communal disputes. Intergroup trade has become dangerous and has decreased dramatically. Malians report a sense of helplessness: they want to trade, but fear being taken advantage of or worse (Human Rights Watch 2017).

To make matters worse, since 2015, violence against the Malian authorities and their perceived supporters has spread from Tuareg to Peulh communities. The success of the

\footnotetext{
${ }^{14}$ Mandé denotes a socio-linguistic culture shared by a majority of Malians, though it encompasses many different ethnic groups (Conrad and Conde 2004).
} 
armed Tuareg movement paved the way for recruitment among the Peulh. To be clear, many of these conflicts begin as localized disputes between individuals, families, tribes, and clans over matters such as land, the rule of law, and other parochial grievances (Group 2016). However, individuals organize the responses to their disputes along ethnic lines. Although many clashes are between fishing, merchant, pastoralist, and agricultural families, those functional divisions mirror ethnic classifications. For example, members of the Peulh ethnic group tend to be overwhelmingly cattle herders while members of the Dogon ethnic group tend to be farmers (Imperato and Imperato 2008). Elite narratives from Malian authorities and armed groups alike have also increasingly framed disputes in the country as ethnic in nature (Tull 2019).

Three sources of agitation by armed groups have complicated Mali's internal divisions. First, Islamic extremist groups, which previously recruited mainly among the Tuareg, have begun recruiting among the Peulh as well. Predatory behavior from the Mandé (non-Peulh) government has generated new opportunities to recruit. In addition, these groups have exploited attacks by the Malian military to bolster resistance to the Malian government and MINUSMA. The second source of conflict is that new Peulh-based armed groups have emerged, including the Macina Liberation Front (MLF), an Islamic extremist group, and l'Alliance nationale pour la sauvegarde de l'identite peule et la restauration de la justice (ANSIPRJ), a secular group agitating for Peulh rights. A July 2016 attack on the government military base in Nampala (in the Segou region of central Mali) killed 19 soldiers and wounded 35 (Human Rights Watch 2016). Both the MLF and ANSIPRJ claimed responsibility. In 2017, Peulh-based and non-Peulh-based Islamic extremist groups joined forces to form Jama'a Nusrat ul-Islam wa al-Muslimin, one of the most potent threats to peacebuilding operations in the region (Tull 2019). Finally, the spread of Islamic extremist groups and the rise of Peulh-based groups has also inspired the creation of non-Peulh militias to combat Peulh violence. Dozo militias, named so after a local word for "hunter," are one example of 
loosely organized self-defense group. Dan Na Ambassagou, an ethnic Dogon militia whose name means "hunters who trust in God," has killed hundreds of Peulh civilians (Diallo 2017).

In response to growing communal tensions, France and the UN have both deployed forces to prevent the escalation of violence. Following its military interventions to combat growing violent extremism in the region (Operation Serval and Operation Barkhane), France has deployed patrols to rural areas in northern and central Mali with the specific goal of preventing communal violence (Gillier 2015). MINUSMA employs military and police forces with a mandate to prevent the escalation of disputes. Short-range patrols give communities the opportunity to report crimes and register local grievances. For example, UN police in major population centers have routine, daily patrolling routes that they use to monitor ongoing interactions and disputes between Malians from different ethnic groups. Additionally, MINUSMA deploys long-range patrols that accompany Malians to weekly markets outside of major population centers to encourage trade and protect them from intergroup predation. ${ }^{15}$ For instance, UN patrols in northern Mali routinely accompany cow herders to markets outside of secure city centers to make sure the herders and the farmers they interact with at these markets do not cheat or steal from their trading partners, who are frequently from another ethnic group. In January 2020, the UN launched "Operation Buffalo," an intensive series of patrols in central Mali designed to monitor ongoing disputes and swiftly respond to any escalations.

\section{Case Selection}

I carried out the field components of this study in 2016 and 2017. At that time, the ethnic conflict between Tuareg separatists and the Malian government had receded as a threat to the country's stability, but pockets of communal violence driven by breakdowns in cooperation remained (Nomikos 2021). Peacekeeping patrols seeking to prevent these breakdowns are

\footnotetext{
${ }^{15}$ Author interview with MINUSMA Police Commissioner, August 3, 2016.
} 
likely to be less effective in Mali than they would be in other settings, which makes the country a difficult test for my hypotheses. As one of sub-Saharan Africa's poorest and most underdeveloped states, Mali lacks the institutional and infrastructural capacity to support large peacekeeping operations, which rely on domestic roads, bases, and airfields to deploy troops where needed. The country's size, demographics, and geography further complicate peacekeeping patrols' efforts to project power: Mali is one of Africa's ten largest and least densely populated states, more than half of its land area is covered by the Sahara Desert, and a large mountain range on the northern border with Algeria provides ideal hiding places for violent actors (Fearon and Laitin 2003).

Moreover, Mali is an especially difficult test case to assess the effectiveness of UN peacekeepers as international enforcers. Because French and UN troops deployed at nearly the same time, in similar areas, and often carry out similar missions, civilians occasionally confuse the two. UN peacekeepers thus have fewer distinct advantages in Mali than in other settings, which may have a clearer division of labor between international actors. Since the deployment of the UN in 2013, more peacekeepers have died in Mali than in any other peacekeeping operation, often in high-profile setbacks that make national news in the country. For example, during the first week of the study, extremists attacked a UN base with mortars, gunfire, and a truck bomb, killing five and wounding 30 more (Diallo and Diarra 2016).

As a general matter, Mali is one of few locations where the role of UN peacekeeping troops resembles that of troops from a military intervention. However, it is plausible that the Malian case represents a skewed comparison given the negative perceptions of former colonizers such as France. To alleviate these concerns, I complement the generalized comparison between France and the UN with a more targeted comparison of the effectiveness of UN peacekeepers from Togo and Senegal. Operating under the UN banner and hailing from neighboring West African countries, these troops differ primarily in how Malians perceive their relative impartiality. For these reasons, I expect the article's findings to generalize to other conflict 
settings with international peacekeeping operations.

\section{Survey Experiment}

To test the hypotheses, I implemented a survey experiment with 874 Malian respondents sampled over two rounds. I conducted the first round in July-August 2016 in eight randomly selected peripheral neighborhoods of Bamako, the capital city. I conducted the second round in December 2017 in 12 villages in the Markala and San communes (districts) in the Segou region of Central Mali. ${ }^{16}$ Four enumerators under my supervision conducted tabletassisted, in-person interviews with each respondent. I outline the recruitment procedure and implementation protocol in full in the Appendix.

The survey began with a set of basic demographic questions and baseline questions about international actors that were identical for all respondents. Next, all respondents received a vignette describing a communal dispute that I designed to resemble a land dispute over cattle between two families from different ethnic groups:

Before the war, [family 1] ${ }^{17}$ herded their 80 cows on land which they owned. [Family 1] had bought the cows over many years and had owned this land for 35 years. In December 2013, [family 1] was forced to leave their land and cows under threat of violence from armed bandits. When they left, [family 2] seized the land and the cows that were left on the land. When [family 1] returned to their land earlier this year, [family 2] refused to give or sell the land or the cows back to them. Some of [family 1] now wants to take back their land and cows by threatening [family 2] using guns.

I randomly assigned respondents to either a control group or one of two treatments. Respondents were balanced on demographic covariates across treatments (see Table 1). Respondents in the control group received no further information. Those in the first treatment

\footnotetext{
${ }^{16}$ The delay between the two rounds was due to outbreaks of communal violence in Segou, which forced me to postpone the second round in order to ensure the safety of the research team and the participants.

${ }^{17}$ I randomly varied the names of the families between four different names in order to avoid any bias due to specific association with a family name.
} 
Table 1: Summary Statistics and Balance on Demographic Covariates between Treatments

\begin{tabular}{|c|c|c|c|c|c|c|c|c|c|}
\hline & \multicolumn{3}{|c|}{ Mean } & \multicolumn{3}{|c|}{ Difference } & \multicolumn{3}{|c|}{$\mathrm{p}$-value } \\
\hline & Control (C) & France (Fr) & $\mathrm{UN}$ & Fr-C & UN-C & Fr-UN & Fr-C & $\mathrm{UN}-\mathrm{C}$ & Fr-UN \\
\hline Age & 34.54 & 35.40 & 36.24 & 0.86 & 1.70 & -0.84 & 0.43 & 0.14 & 0.46 \\
\hline Female & 0.33 & 0.30 & 0.33 & -0.04 & -0.01 & -0.03 & 0.34 & 0.86 & 0.45 \\
\hline Children & 2.84 & 2.98 & 2.93 & 0.14 & 0.08 & 0.05 & 0.61 & 0.75 & 0.85 \\
\hline Education (0-9) & 3.00 & 2.98 & 3.18 & -0.01 & 0.19 & -0.20 & 0.96 & 0.45 & 0.43 \\
\hline Employment (0-3) & 1.48 & 1.58 & 1.55 & 0.10 & 0.08 & 0.03 & 0.32 & 0.47 & 0.80 \\
\hline Victimized & 0.30 & 0.32 & 0.32 & 0.01 & 0.01 & 0.00 & 0.72 & 0.72 & 1.00 \\
\hline
\end{tabular}

group were told that two UN peacekeepers in the area discovered the dispute between the two families. Respondents in the other treatment group were told that two peacekeepers from France came across the dispute. After presenting respondents with the vignette and treatment, I asked them how likely they thought it was that violence would break out. Respondents could answer on a five-point scale, but for ease of interpretation I recoded the outcome as a binary variable in which "very likely" or "likely" are coded as 1 and all others 0.

\section{Results}

Figure 2 visualizes the main results. The points in the figure display the mean proportion of respondents that said the communal dispute in the vignette was likely or very likely to become violent. Among those assigned to a dispute without a peacekeeper present, $42 \%$ believed it would become violent. The magnitude of this large minority-more than two out of five in the sample - suggests how volatile Malians perceive communal disputes to be.

The results show that UN peacekeepers reduce the likelihood that a dispute will escalate. The percentage of respondents who were told that UN peacekeepers discovered the dispute who thought violence was likely was less than half that of the control group, at $19 \%$. This 23-percentage-point difference is statistically significant at the $95 \%$ level. Additionally, I 
Figure 2: Assignment to UN Treatment Reduces Likelihood that Respondents Predict the Dispute will Escalate

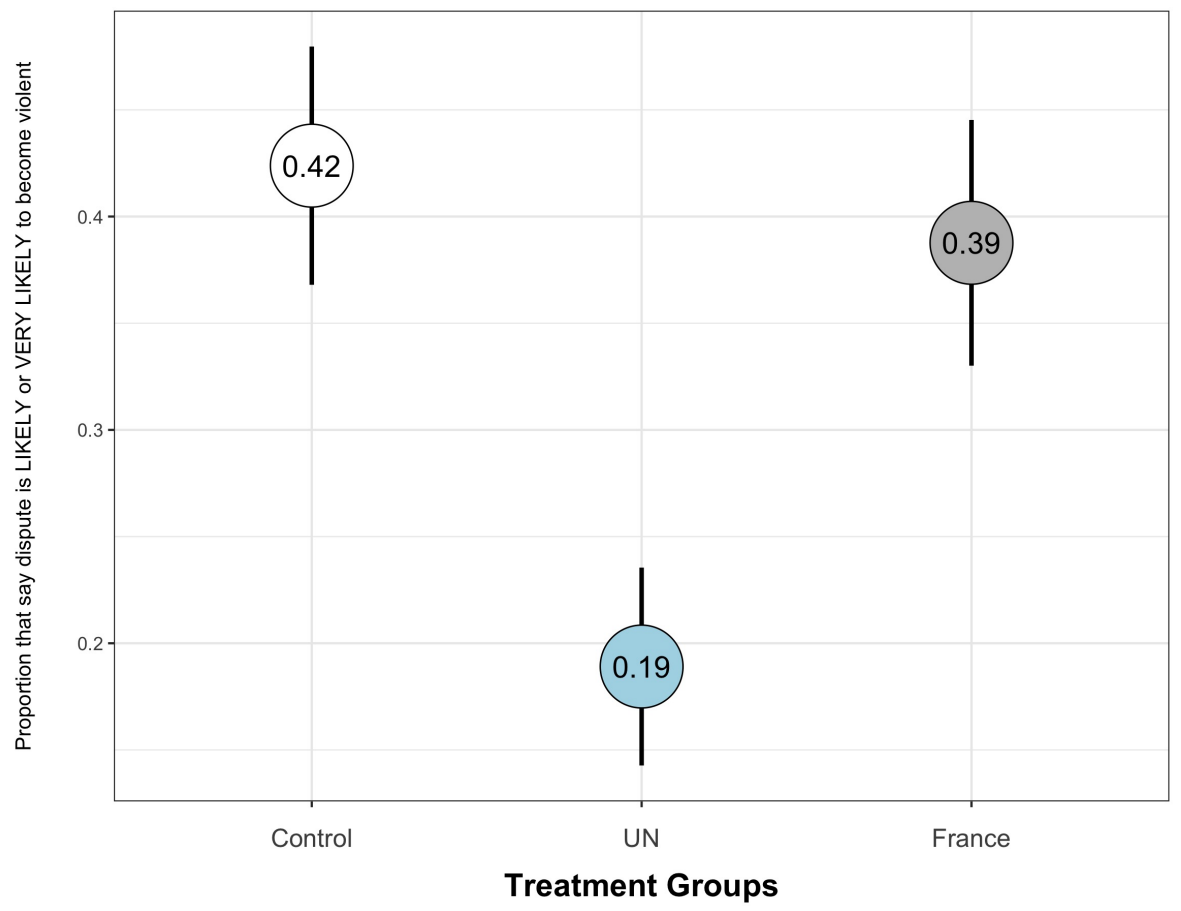

Note: Points indicate means. Lines represent $95 \%$ confidence intervals. I assigned 305 respondents to the control group, 282 to the France treatment group, and 287 to the UN treatment group.

find that French peacekeepers do not have the same anticipated effect on communal violence. Almost as high a percentage of respondents assigned to French peacekeeping patrols predicted the dispute would become violent $(39 \%)$ as in the control group. The difference is not statistically significant at conventional levels. Moreover, assignment to the UN peacekeeping treatment decreases the predicted probability of dispute escalation by $20 \%$ compared to assignment to French peacekeeping. This difference suggests that UN peacekeepers are perceived to be more effective at containing communal disputes than peacekeepers from France. 


\section{Discussion: Investigating the Mechanisms}

In order to investigate perceptions of peacekeepers in greater depth, I asked respondents in the second round of the survey a series of questions about the characteristics of UN peacekeepers and French soldiers. I also included questions about particular characteristics of peacekeepers that prior research suggests may be salient. Figure 3 displays the mean proportion of respondents who say that a given characteristic applies to either French or UN peacekeepers.

The results suggest that the belief that UN peacekeepers do not favor certain ethnic groups drives their perceived effectiveness in preventing the escalation of communal conflicts. The only statistically and substantively significant difference across all characteristics is the proportion of respondents that reported that UN peacekeepers or French soldiers "do not favor any ethnic group." Whereas nearly $80 \%$ of all respondents think of UN peacekeepers as impartial, fewer than $40 \%$ say the same about French soldier (see highlighted box in Figure $3)$.

The results also show that nearly half of the respondents see peacekeepers patrolling and about a quarter have conversations with them, which supports arguments that contact with populations helps international actors resolve local disputes. However, the survey does not indicate that peacekeepers, especially from the UN, have any specific localized knowledge. Less than a third of all respondents said that peacekeepers knew about their specific local disputes or had formed relationships with their traditional leaders.

Not all reported perceptions were positive. Sexual exploitation by UN peacekeepers was mentioned by $7 \%$ of respondents, who said women in their village had been victims. The same percentage of respondents reported SEA by French troops. These numbers are highly concerning; they also suggest that social desirability bias is not driving the results in favor of the UN. In addition, they might at least partly explain why $19 \%$ of those in the UN

peacekeeeping treatment group thought a dispute would escalate even in the presence of 
Figure 3: Comparing Perceptions of UN Peacekeepers and French Soldiers in Central Mali.

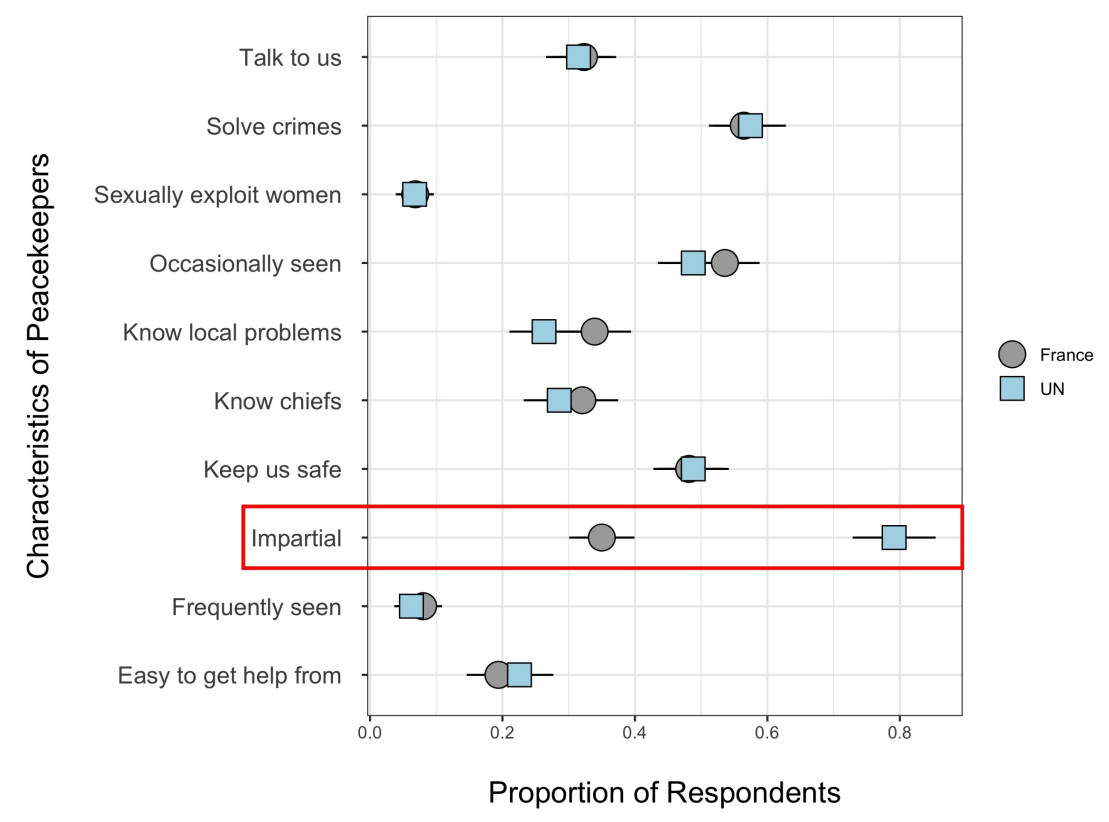

Note: Points indicate means. Lines represent $95 \%$ confidence intervals.

the UN. Respondents who believe that UN peacekeepers sexually exploit women will likely have a harder time believing that UN peacekeepers will support the peaceful resolution of a communal dispute (Karim and Beardsley 2017).

My theoretical framework implies that perceptions of the UN as impartial mediate UN peacekeepers' ability to contain local disputes. To further investigate the plausibility of this mechanism, I added questions at the end of the survey to assess whether respondents believed the UN or France favored any particular ethnic group. I constructed a new variable, IMPARTIAL, that takes a value of 1 if a respondent said they did not perceive the international actor in their vignette as favoring a certain group, and 0 otherwise. I also code another variable, UN_TREATMENT, that takes a value of 1 if a respondent received the UN treatment and 0 if they received the France treatment. I omit respondents in the control group because any analysis of the perception of international actor impartiality requires the presence of an international actor. 
Table 2: Perceptions of Impartiality Mediate International Actors' Ability to Contain Disputes

\begin{tabular}{|c|c|c|c|c|}
\hline & \multicolumn{2}{|c|}{ Perception as Impartial } & \multicolumn{2}{|c|}{ Dispute Likely to Escalate } \\
\hline & $(1)$ & $(2)$ & $(3)$ & $(4)$ \\
\hline \multirow[t]{2}{*}{ UN_TREATMENT } & $0.239^{* * *}$ & $0.300^{* * *}$ & $-0.199^{* * *}$ & $-0.139^{* * *}$ \\
\hline & $(0.044)$ & $(0.050)$ & $(0.038)$ & $(0.051)$ \\
\hline \multirow[t]{2}{*}{ IMPARTIAL } & & & & $-0.125^{* *}$ \\
\hline & & & & $(0.050)$ \\
\hline Controls & No & Yes & No & Yes \\
\hline Observations & 493 & 377 & 551 & 377 \\
\hline \multicolumn{5}{|c|}{${ }^{*} \mathrm{p}<.1 ;{ }^{* *} \mathrm{p}<.05 ;{ }^{* * *} \mathrm{p}<.01$} \\
\hline \multicolumn{5}{|c|}{$\begin{array}{l}\text { Notes: This table reports the coefficient estimates from ordinary least squares re- } \\
\text { gression models with standard errors in parentheses. In all models, UN_TREATMENT } \\
\text { is a binary indicator for whether respondents received the UN peacekeeping treat- } \\
\text { ment, with French peacekeeping as the reference category. In Models } 1 \text { and } 2 \text {, the } \\
\text { dependent variable is a binary indicator for whether the respondent perceived the } \\
\text { international actor in the vignette as impartial. In Models } 3 \text { and } 4 \text {, the dependent } \\
\text { variable is a binary indicator for whether respondents said the dispute was likely to } \\
\text { become violent or not. }\end{array}$} \\
\hline
\end{tabular}

The evidence suggests that assignment to the UN peacekeeping treatment increases the likelihood that respondents will say that the international actor that discovered the dispute was impartial. In Models 1 and 2 of Table 2, I regress perception of the international actor as impartial on assignment to UN peacekeeping. I find that respondents who are told a UN peacekeeping patrol discovered a dispute are 24-30\% more likely - depending on the model specification - to say it is impartial than those who are told a French peacekeeping patrol first came across the dispute.

The regression results also show that perceptions of impartiality are associated with a lower likelihood of dispute escalation. Model 3 in Table 2 reproduces the results displayed in Figure 2: UN peacekeepers decrease the likelihood that an individual says a dispute will escalate by nearly $20 \%$ relative to French peacekeepers. This effect is robust to including 
the measure of impartiality (see Model 4). However, the magnitude of the UN peacekeeping effect drops to $14 \%$. In addition, the regression results suggest that individuals who perceive the peacekeeping patrol as impartial are $12.5 \%$ less likely to say that a dispute will escalate compared to those who say that peacekeepers are not impartial. The fact that the magnitude of the association decreases when perceptions of impartiality are included suggests that these perceptions drive at least part of the effect of UN peacekeeping patrols.

Next, I investigate whether my proposed mechanism - perception of the UN as impartialaccounts for the observed difference in effect size between UN and French peacekeeping. Although the above discussion suggests that impartiality does mediate at least part of the effect of the UN treatment, it is not clear how large this mediated effect is. To calculate the magnitude of the mediated effect, I employ a nonparametric causal mediation model developed by Imai et al. (2011) for use with the mediation package in R.

While the treatment was randomly assigned, the mediator (impartiality) was not. Thus for the estimates in the following analysis to be valid, two conditions must be met as part of what's called the sequential ignorability assumption. First, the analysis must be adjusted for all pretreatment confounders that could cause both impartiality (the mediator) and the outbreak of violence (the outcome). Although I cannot be sure that I have included all potential confounders, since there will always likely be some unobservable variables present that introduce bias, I include a series of control variables to alleviate this concern: LIST CONTROLS.

The second condition is that there should be no posttreatment confounders, meaning that there should not be a causal relationship between impartiality and other mediators. And indeed, there is no reason to expect that perceptions of impartiality would cause other mediators or vice versa. That is, it is unlikely that assignment to UN treatment has a causal relationship with a variable shifts perceptions of impartiality to through another mechanism that also changes beliefs about whether a communal dispute will become violent. 
Figure 4: Estimated Size of the UN Treatment Effect, by Mediator

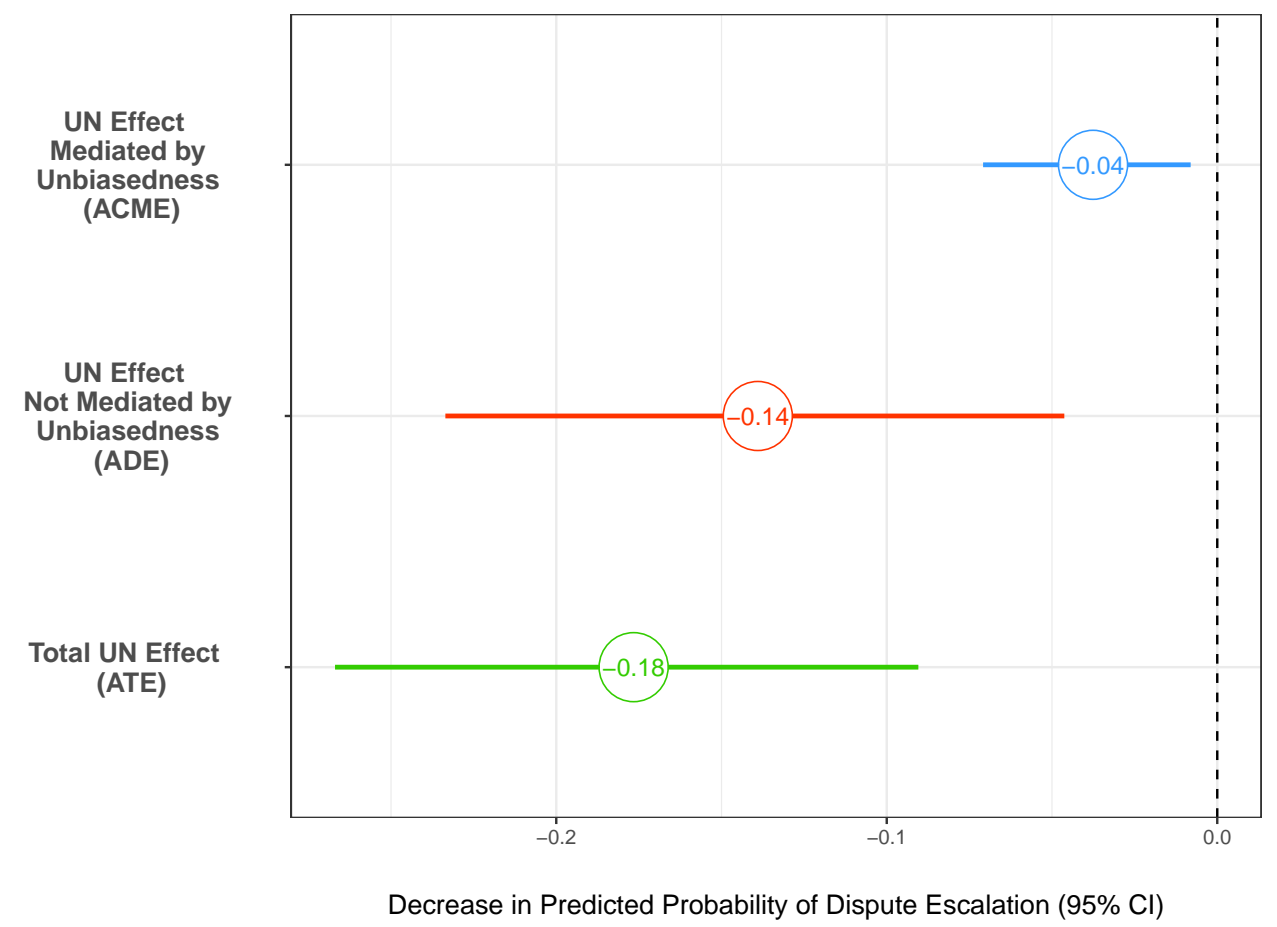

As Figure 3 illustrates, assignment to the UN treatment relationship does not shift beliefs about any other characteristic of the international intervener. Moreover, I find no evidence of a relationship between any of these characteristics - potential posttreatment confoundersand respondents' beliefs about violence breaking out - the outcome variable of interest. ${ }^{18}$

The causal mediation model decomposes the average treatment effect (ATE) into two components: (1) the average causal mediation effect (ACME), the part of the ATE that is caused by the proposed mediator (impartiality in this case) and (2) the average direct effect (ADE), the remaining part of the ATE effect size, which is attributed to other potential causes.

I find that the respondents believe the UN presence decreases the likelihood of dispute escalation because locals perceive it to be impartial. That is, perceptions of UN impartiality

\footnotetext{
${ }^{18} \mathrm{I}$ report full results of these regressions in the Appendix.
} 
drive a significant part of the ATE. Figure 4 displays the total estimated UN effect (the ATE) at the bottom. It shows that assignment to UN peacekeeping patrols decreases the proportion of respondents who say disputes escalate by $18 \%$ relative to assignment to French peacekeeping patrols. ${ }^{19}$ The figure displays the magnitude of the effect due to the proposed mediator (ACME) at the top: 0.04 of the $0.18 \mathrm{UN}$ effect is due to perceptions that the UN is impartial - a substantively and statistically significant effect. Perceptions of the UN as impartial account for nearly one-quarter of its predicted effectiveness on their own. All other differences between France and the UN combined account for the remaining three-quarters of the estimated difference in effect magnitude.

\section{Investigating the Real-World Impact of Peacekeepers}

The survey experiment provides evidence that is in line with the Hypotheses 1 and 2 - that perceptions of the UN as relatively impartial account for its effectiveness. To investigate whether these findings generalize to real-world operations, I examine UN peacekeeping efforts to prevent the onset of communal violence in the central Malian region of Mopti. Rather than comparing UN peacekeeping in a country with a peacekeeping operation to a country without one, I compare UN peacekeepers from one contributing country to those from another country deployed to the same area. The selection of Mopti as a case study facilities comparative analysis because UN patrols in the region are composed of troops from a small set of countries, primarily Togo and Senegal. Examining peacekeeping in Mopti also allows me to test the implications of Hypothesis 3, namely that UN peacekeepers from a contributing country without similar identity cleavages will be more effective than those with similar identity cleavages.

\footnotetext{
${ }^{19} \mathrm{I}$ use the results from Models 2 and 4 in Table 2 to derive the ACME, ADE, and ATE, which is why the UN effect size is slightly different than in other models. I construct a $95 \%$ quasi-Bayesian confidence interval derived from 1,000 simulations.
} 
Although both Togo and Senegal are Francophone countries located in West Africa, ethnic power relations in the two countries differ in important ways. In particular, members of the pastoralist Peulh ethnic group figure prominently into the politics of central Mali and Senegal, but not Togo. The vast majority of the nearly 3 million Peulh that reside in Mali live in Mopti where political, religious, and traditional leaders have long fought for their community's place in Malian society. In Senegal, the Peulh are one of several influential minority groups in national politics (Creevey, Ngomo and Vengroff 2005). They have also consolidated political power in large swaths of northeastern Senegal as governance has become more decentralized following decades of reform (Wilfahrt 2018). By contrast, Peulh make up only about $1 \%$ of the Togolese population with little to no influence on Togolese society. Moreover, politics in Togo have in recent years begun to coalesce nationally with ethnicity becoming less salient than in previous points in the country's history (Brown 1983; Seely and Decalo 2021).

Because ethnic power relations in central Mali resemble those in Senegal but not in Togo, Malians are more likely to perceive Togolese peacekeepers as impartial. In turn, the implication of my theory is that Togolese peacekeepers are better suited than Senegalese peacekeepers at preventing the onset of communal violence in Mopti where disputes between Peulh and other ethnic groups abound. Comparing the efficacy of these peacekeepers from these countries, deployed at a similar time in the same region, allows me to hold constant potential factors that might otherwise explain the differences in outcomes related to communal violence.

\section{Data and Estimation Strategy}

To analyze the relationship between the nationality of peacekeepers and their ability to

prevent communal violence, I use a time-series cross-sectional dataset of peacekeeping deployments to Mopti, the region of Mali with the greatest amount of communal violence. The 
Figure 5: Communal Violence in Mali, 2014-2020

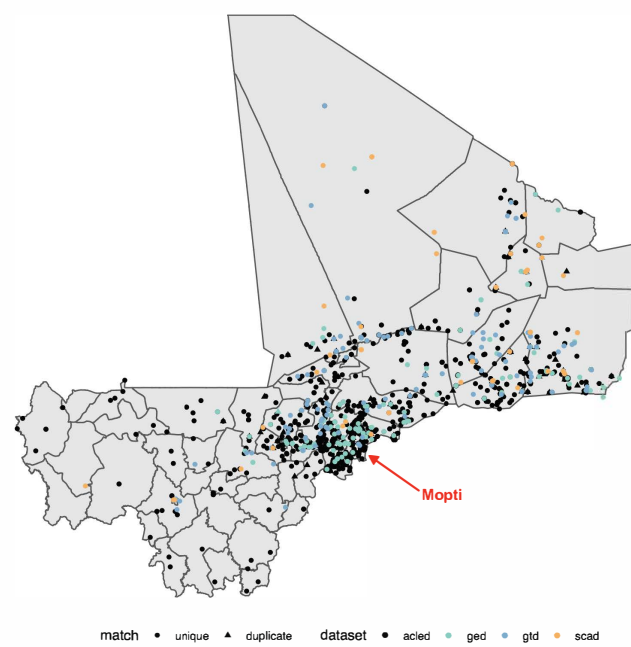

(a) Georeferenced by event and dataset

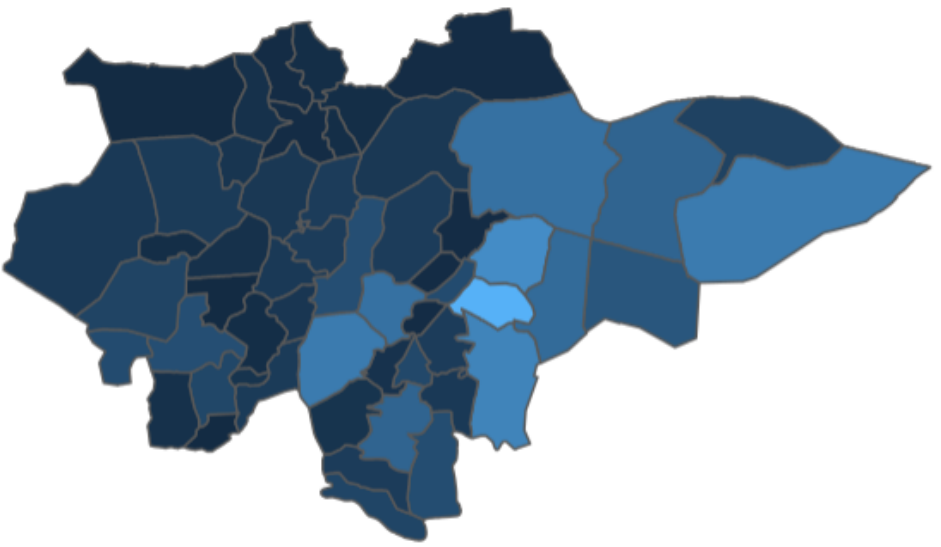

Count of communal violence events

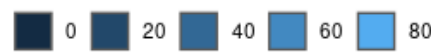

(b) Total communal violence in Mopti, by commune

unit of analysis is the commune-month, subsetted entirely to the region of Mopti. Communes are the third-level administrative district in Mali (ADM3) and the smallest administrative district for which there is systematic data collection. I examine every month of available data from April 2014, the beginning of the Togolese and Senegalese deployments, to December 2019, the most recent month with complete data on the necessary variables.

I use a binary coding of the onset of communal violence from multiple event-based datasets as the dependent variable. Since I conceptualize communal conflict primarily as violence in which none of the actors is the state, I operationalize it in a similar manner: I code a commune-month as having communal conflict if there is violence between two nonstate actors in that month in that commune. I use a binary coding of the outcome variable because I am interested in measuring the effectiveness of peacekeepers in preventing the onset of any type of communal conflict. ${ }^{20}$

\footnotetext{
${ }^{20}$ For practical purposes, there were almost no cases of more than one communal conflict in commune in a single month. So the results of the analysis would not change with alternative codings.
} 
Given that communal conflict can take many forms, it is unlikely that any one conflict event dataset will include all relevant types of violence. Moreover, some datasets may reflect specific reporting inaccuracies that may lead to biased estimates (Eck 2012). Accordingly, I combine data from the Armed Conflict Location and Event Dataset (ACLED), the UCDP Georeferenced Event Dataset (GED), the Social Conflict Analysis Database (SCAD), and the Global Terrorism Database (GTD) to capture the broadest possible spectrum of communal violence (LaFree and Dugan 2007; Raleigh et al. 2010; Sundberg, Eck and Kreutz 2012; Salehyan et al. 2012). To avoid double counting events, I use a deterministic algorithm to identify groups of two or more events from the datasets that potentially refer to the same empirical occurrence. The algorithm functions by identifying all events that fall within given date and distance window of other events, and then detects likely double reports using event features such as actor identity, event type, or confidence in the geocoding provided by the dataset. After running the program, I examined each observation by hand to confirm the precision and accuracy of the data, ensuring that every observation captured a unique observation of the onset of communal violence. ${ }^{21}$

Figure 5 maps all the communal violence events in the dataset. It indicates that most of the violence is clustered around Mopti, suggestive of the instability in the region. It also highlights the variability in the onset of communal violence across Mopti itself, with most conflict breaking out in the eastern communes.

The explanatory variables are counts of UN peacekeeping troops from Togo and Senegal. I use data from the Robust African Deployment of Peacekeeping Operations (RADPKO) dataset to measure the number of peacekeepers deployed to Togo and Senegal in a communemonth in Mopti. RADPKO collects monthly data from publicly available UN reports on the location of UN peacekeeping deployments, divided by every peacekeeping-contributing

\footnotetext{
${ }^{21}$ For more detail on the programming of the algorithm, see Appendix. I use the approach detailed in Donnay et al. (2019) and implement it with the meltt package in R developed by Karsten Donnay and Eric Dunford.
} 
Figure 6: Average Togo and Senegal Troop Deployment

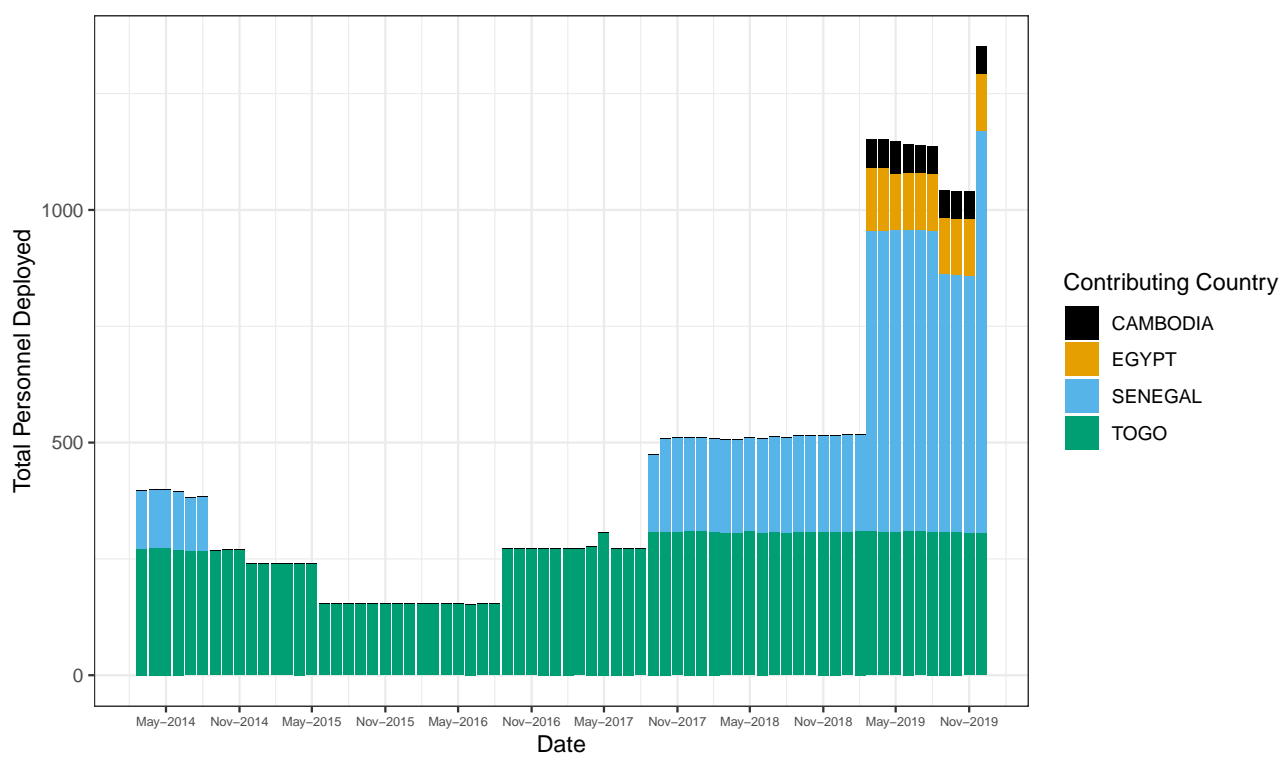

country. $^{22}$ As Figure 6 shows, these two countries account for the vast majority of troop deployments in the area. Although there are some minor exceptions - such as a small number of Cambodian and Egyptian peacekeepers deployed in late 2019 - these troops perform primarily technical duties such as mine and improvised explosive device detection. ${ }^{23}$

I estimate the association between peacekeepers and onset of violence using logistic regressions models since the outcome is a binary variable. ${ }^{24}$ I adjust for a set of potential covariates that might be associated with both deployment patterns and the onset of conflict in order to mitigate omitted variable bias. Given the importance of geographical distance, infrastructure, and terrain to the effectiveness of peacekeeping troops (Ruggeri, Dorussen and Gizelis 2017), I include measures of the distance between the commune and the nearest peacekeeping base, the level of development in the commune as measured by night-time lu-

\footnotetext{
${ }^{22}$ For more on the coding protocol, see Hunnicutt and Nomikos (2020). The monthly data is a unique feature of the RADPKO data, making it more suitable for sub-national, time-series analyses than other UN data. See Bove, Salvatore and Elia (2021) for a recent such application using RADPKO.

${ }^{23}$ I include counts of Cambodian and Egyptian peacekeepers as controls to adjust for these deployment patterns in all models.

${ }^{24}$ Results are robust to using OLS instead of logistic regressions. See the Appendix.
} 
minosity, and the ruggedness of the terrain as measured by the average elevation multiplied by slope in a commune. The models also account for temporal dependence between units using a cubic polynomial (Carter and Signorino 2010). Finally, I add fixed effects at the level of the cercle, the second-level administrative district (ADM2), to account for potential differences between units that the covariates may not capture. ${ }^{25}$ I include robust standard errors clustered at the level of the cercle.

\section{Potential Threats to Inference}

Before proceeding, I discuss three potential threats to causal inference and my strategy for mitigating them.

First, the strategic nature of UN peacekeeping deployment may introduce selection bias because UN peacekeepers do not patrol conflict settings at random. For the purposes of my analysis, deployment patterns are primarily a concern if peacekeepers go to safe areas rather than where they are needed most. This would lead to a spurious negative association between deployment patterns and the onset of communal violence. However, looking at the broad patterns of deployment in Mali, I find that peacekeepers deploy in a way that best contributes to conflict resolution rather than where the risk of attack is low. ${ }^{26}$ Nor do I find evidence of a large temporal lag between violence and deployment. In other words, UN peacekeepers go where the can help prevent violence, not where there is the least amount of conflict. Additionally, as discussed above, I control for the geographic characteristics of the commune to account for selection bias that may arise from decisions by peacekeepers to avoid areas that are difficult to reach. Finally, given that I compare peacekeepers from two West African countries under the same UN command structure, there is no reason to expect

\footnotetext{
${ }^{25}$ I report fixed effects at the cercle level in the main body of the article but report results with fixed effects at the commune level in the Appendix.

${ }^{26}$ I find that peacekeepers follow what Ruggeri, Dorussen and Gizelis (2018) call an "instrumental logic" rather than a "logic of convenience." See the Appendix for a more detailed analysis of deployment patterns.
} 
Table 3: Summary of observable implications from theory.

\begin{tabular}{|c|c|c|}
\hline & Main Analysis & Placebo Test \\
\hline & Mopti & Kidal \\
\hline $\begin{array}{c}\text { Togolese } \\
\text { peacekeepers }\end{array}$ & $\begin{array}{l}\text { Perceived as impartial, lower } \\
\text { likelihood of violence }\end{array}$ & $\begin{array}{l}\text { Perceived as impartial, } \\
\text { similar likelihood of violence }\end{array}$ \\
\hline $\begin{array}{l}\text { Senegalese } \\
\text { peacekeepers }\end{array}$ & $\begin{array}{l}\text { Perceived as biased, higher } \\
\text { likelihood of violence }\end{array}$ & $\begin{array}{l}\text { Perceived as impartial, } \\
\text { similar likelihood of violence }\end{array}$ \\
\hline
\end{tabular}

Note: Each cell lists whether Malians will perceive peacekeepers from the given country of origin (Togo or Senegal) as impartial in the given Malian region of deployment (Mopti or Kidal) and what the relative likelihood of communal violence is.

that concerns related to selection could explain differences between the two.

A second potential issue is that the dataset does not capture the entire universe of communal disputes and whether or not they became violent. I mitigate this concern by looking at a cross-section of data recording violent events in localities in one specific region of a country where communal disputes are pervasive. Theoretically, each commune within this region, Mopti in Mali, should have similar numbers of disputes and a similar likelihood of onset of violence, all else equal. By measuring whether a specific time and place contained communal conflict, the data reflect whether these localities with similar dispute propensities became violent.

Finally, a critical concern is whether the results actually reflect the proposed mechanism related to perceptions of impartiality or another mechanism altogether. I address this issue using a multifaceted design-based approach that tests potential observable implications from the theory compared to alternative mechanisms (see Table 3). According to the logic of my theory, the deployment of Togolese but not Senegalese peacekeepers should be negatively associated with the onset of communal violence. Moreover, this relationship should be local- 
ized to the region of Mopti since ethnic power relations there resemble those in Senegal but not Togo. I test this implication by conducting a placebo test using data from another region of Mali, Kidal, that has entirely different ethnic power relations than either Senegal or Togo. Given the lack of ethnic connection to the domestic populations, Malians living in Kidal will likely perceive both Togolese and Senegalese peacekeepers as impartial. Consequently, my theory predicts that peacekeepers from both contributing countries will be equally effective.

\section{Results}

I report the results of the main empirical estimations in Table 4. Across all models, the magnitude and direction of the estimated coefficients remain consistent, which suggests two robust patterns. First, across all models, Togolese peacekeepers are negatively associated with levels of communal violence at a statistically significant level $(p<0.001)$. Second, across all models, Senegalese peacekeepers are not negatively associated with levels of communal violence, which suggests they have a different relationship with violence than their Togolese counterparts.

For ease of interpretation, I use these result to estimate the predicted probabilities of violent escalation (see Figure 7). ${ }^{27}$ Panel (a) shows that an increase in the number of Togolese peacekeepers deployed to a given area in a given month from 0 to 500 is associated with a decrease in the predicted probability of communal violence, from about $0.14(95 \%$ confidence interval: $[0.08,0.23])$ to roughly $0.02[0.01,0.03]$. Panel (b) shows that a similar increase in Senegalese peacekeepers is not associated with a statistically significant change in the predicted probability of communal violence.

Returning to actual deployment levels, as visualized in Figure 6, offers another way to understand the significant of these results. In March 2014, the UN deployed 352 Togolese

\footnotetext{
${ }^{27}$ Coefficients from Model 1. Controls held at mean.
} 
Table 4: Logit regression results, communal violence onset in Mopti region, Mali. Robust, cercle-clustered standard errors.

Onset of Communal Violence

\begin{tabular}{lccccc} 
& $(1)$ & $(2)$ & $(3)$ & $(4)$ & $(5)$ \\
\hline Togo Troops (1000s) & $-3.969^{* * *}$ & $-3.474^{* * *}$ & $-3.874^{* * *}$ & $-3.407^{* *}$ & $-4.774^{* * *}$ \\
& $(0.954)$ & $(0.964)$ & $(1.009)$ & $(1.039)$ & $(0.918)$ \\
Senegal Troops (1000s) & 0.319 & 0.549 & -0.293 & 0.203 & $4.740^{*}$ \\
& $(1.759)$ & $(1.641)$ & $(1.286)$ & $(1.281)$ & $(2.130)$ \\
\hline \hline & $N O$ & $N O$ & $N O$ & $N O$ & $Y E S$ \\
Cercle Fixed Effects & $N O$ & $Y E S$ & $N O$ & $Y E S$ & $Y E S$ \\
Domestic Controls & $N O$ & $N O$ & $Y E S$ & $Y E S$ & $Y E S$ \\
Time trend adjusted & 3656 & 3656 & 3656 & 3656 & 3656 \\
Observations & & &
\end{tabular}

${ }^{*} \mathrm{p}<.05 ;{ }^{* *} \mathrm{p}<.01 ;{ }^{* * *} \mathrm{p}<.001$

peacekeeping troops to the UN base near the commune of Douentza in Mopti. ${ }^{28}$ According to my results, this increase will be associated with a drop in the predicted probability of communal violence from in Douentza from $0.14[0.08,0.23]$ to 0.04 [0.03, 0.05]. In August 2016, the UN further raised Togolese troop levels in Douentza to 534, which my model predicts would be associated with a decrease in the predicted probability of communal violence from $0.04[0.03,0.05]$ to below $0.02[0.01,0.03]$. For comparison, consider the deployment of Senegalese peacekeepers to the capital commune of Mopti, also named Mopti. In September 2017, the UN sent 118 Senegalese peacekeepers to Mopti commune, increasing that number to 653 in December 2019. My findings suggest that these changes in deployment levels would not be associated with any changes in the predicted probability of communal violence, which would remain around 0.14 [0.07, 0.23].

I report the results of the placebo test in Table 5. I ran the same models as before with the same peacekeeper types but using data from the Kidal region rather than the Mopti region.

\footnotetext{
${ }^{28}$ Troop numbers from the RADPKO website. See https://dapp-lab.org/radpko for source.
} 
Figure 7: Predicted Probability of Communal Violence, by Nationality of UN Peacekeepers

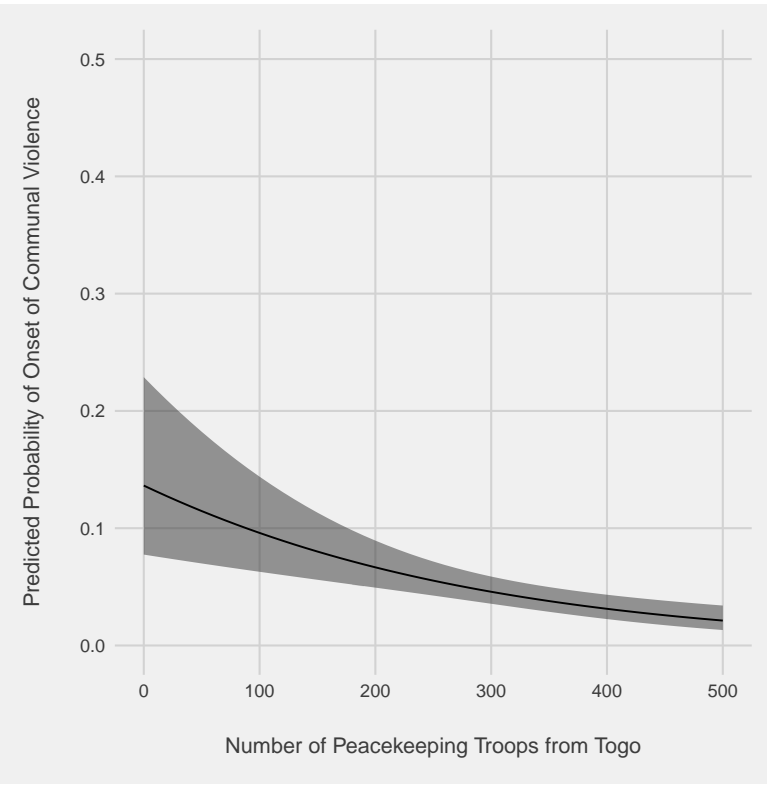

(a) Togolese Peacekeepers

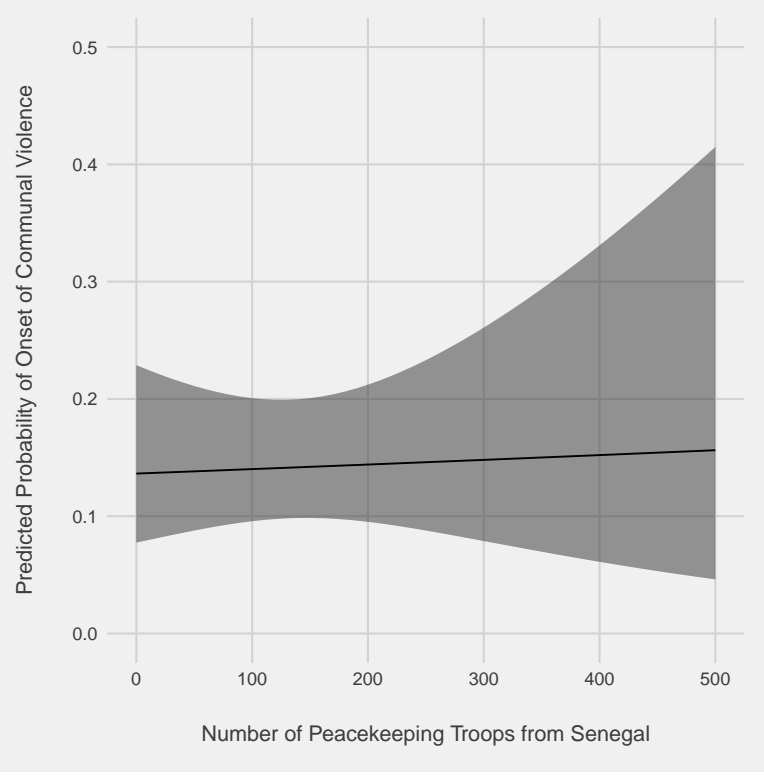

(b) Senegalese Peacekeepers

I find no robust patterns across the models. The deployment of Togolese peacekeepers is associated with a statistically significant decrease in the onset of communal violence in only 2 of the 5 models. Although there is a negative relationship between the deployment of Senegalese peacekeepers and onset of communal violence, it is not statistically significant in any of the models.

The Kidal region is home to an active insurgency and one of the most violent areas to which UN peacekeepers have ever deployed. The active conflict in Kidal likely explains the inconsistency of the results reported in Table 5. Power relations between different Malian ethnic groups in Kidal, which differ in important ways from Mopti, likely account for the similarities between Togo and Senegal. Recall that I theorized that the reason why Senegalese peacekeepers in Mopti would be especially ineffective is because the Peulh, a key minority group in Mopti, have an influential role in national politics in Senegal but not in Togo. As a result non-Peulh Malians are likelier to perceive Togolese rather than Senegalese peacekeepers as impartial. However, the Peulh are less central to society, governance, and conflict in Kidal 
Table 5: Logit regression results, communal violence onset in Kidal region, Mali. Robust, cercle-clustered standard errors.

\begin{tabular}{|c|c|c|c|c|c|}
\hline & \multicolumn{5}{|c|}{ Onset of Communal Violence } \\
\hline & $(1)$ & $(2)$ & $(3)$ & $(4)$ & $(5)$ \\
\hline \multirow[t]{2}{*}{ Togo Troops (1000s) } & -0.257 & $-8.618^{* * *}$ & 1.981 & $-9.574^{* *}$ & -7.732 \\
\hline & $(0.854)$ & $(1.853)$ & $(2.001)$ & $(3.518)$ & $(4.476)$ \\
\hline \multirow[t]{2}{*}{ Senegal Troops (1000s) } & -1.854 & -2.761 & -2.674 & -2.655 & -2.931 \\
\hline & $(1.796)$ & $(2.353)$ & $(2.329)$ & $(3.005)$ & $(3.000)$ \\
\hline Cercle Fixed Effects & NO & NO & NO & NO & $Y E S$ \\
\hline Domestic Controls & NO & $Y E S$ & NO & $Y E S$ & $Y E S$ \\
\hline Time trend adjusted & NO & NO & $Y E S$ & $Y E S$ & $Y E S$ \\
\hline Observations & 804 & 804 & 804 & 804 & 804 \\
\hline
\end{tabular}

than they are in Mopti. Consequently, the differences between Togo and Senegal that matter for peacekeeping outcomes according to my theory are not present in Kidal.

The results of the placebo test are largely in line with a recent case study of MINUSMA by Bove, Ruffa and Ruggeri (2020). In general, they report that Malians perceived the missions as relatively impartial because of the great diversity of peacekeeping contributors. Moreover, they find that a "small distance" between the cultures of contributing countries and Mali accounts for some of the effectiveness of peacekeepers on the ground (p. 163). However, they also caution that Malians perceived some of the troop contingents from neighboring countries as partial, which explained some of the challenges of peacekeeping in the country.

\section{Conclusion}

UN peacekeeping operations have embraced the challenge of preventing communal violence in fragile settings around the globe. Research on the efficacy of these efforts, however, re- 
mains limited and largely speculative. In this article, I develop and test a theory to explain when, where, and how UN peacekeepers are likely to succeed in limiting the outbreak of communal violence. My theory focuses on three day-to-day practices of patrols: enforcing peaceful cooperation between members of different social groups living in the same community, apprehending individuals and groups that might escalate communal disputes, and monitoring ongoing disputes. I identify local perceptions of the impartiality of UN peacekeepers as the key determinant of the effectiveness of these practices. I test my theory using a survey experiment fielded with 874 Malians living in 20 communities in Mali and comparative statistical analysis of the efforts of UN peacekeepers from two different contributing countries operating in two different regions of Mali.

Consistent with my theory, I find that including the presence of UN peacekeeping patrols in a vignette about a communal dispute a communal dispute between two families from different ethnic groups reduces the proportion of Malian respondents who say violence will break out by more than half. A detailed questionnaire following the experiment and formal mediation analysis underscore that the perception of the UN as impartial accounts for a substantial part of this effect. I also document a robust negative relationship between the deployment of UN peacekeepers from Togo and the onset of communal violence in central Mali. Yet I do not find any relationship between the deployment of UN peacekeepers from Senegal to the same area at a similar time and the onset of communal violence. I attribute this difference to the fact that Malians living in this part of the country likely perceive Togolese peacekeepers as relatively more impartial than Senegalese peacekeepers. Taken together, my results highlight a critical mechanism by which UN peacekeepers can provide order and stability in conflict and post-conflict settings.

My findings have at least three important implications for the conduct of UN peacekeeping operations. First, they suggest that the UN should expand its investment in reducing and preventing communal violence. While researchers have long established the ability of 
UN peacekeeping operations to broker peace agreements between leaders of armed groups (Walter, Howard and Fortna 2019), skeptics have pointed instead to outbreaks of communal violence as a critical threat to the stability of settings where peacekeepers deploy (Autesserre 2010, 2015). While the management of communal violence has become a core component of recent multidimensional missions, contributing countries have frequently balked at proving the personnel and materiel necessary to support these efforts (Marijan 2019). My findings indicate that investing resources in these operations would be worthwhile. Given sufficient resources, peacekeepers can mitigate the instability from communal violence and offer wartorn communities a chance to rebuild after conflict.

Second, my results suggest a pathway by which peacekeepers can succeed in conflict settings with large pockets of instability. Recent work in political science has focused on civilian efforts within UN peacekeeping operations to promote the rule-of-law and reduce communal violence in places like Liberia and Côte d'Ivoire (Smidt 2019; Blair 2019, 2020b). However, the success of civilian peacebuilding efforts such as these necessitate the end of violence and the presence of broad-based peace. For better or worse, 21st century multidimensional UN peacekeeping operations typically deploy to countries in places like Mali, the Central African Republic, and South Sudan where there is no national peace to keep. When peacekeepers enforce cooperation, apprehend suspects, and monitor communal disputes as I describe in this article, they can have a positive and important impact in these challenging settings.

Finally, my findings underscore the enduring importance of impartiality to the success of UN peacekeeping operations. As a general rule, domestic populations perceive UN peacekeepers as relatively more impartial than troops from foreign interveners. However, as my analysis of Togolese and Senegalese peacekeeping in Mali reveals, locals may also perceive peacekeepers from some neighboring countries as more impartial than others. The UN is careful not to deploy former colonial occupiers as peacekeepers. These results suggest that the UN should also take local ethnic cleavages into account when making operational deci- 
sions about deployment.

More broadly, my results generalize to other settings and to other kinds of international intervention as well. Communal disputes pervade fragile settings around the world, and preventing the onset of communal violence is integral to the mandates of UN missions stationed abroad. While no other international actor has deployed troops as frequently as the UN, it is not the only foreign intervener that has sought to limit communal violence. Communal disputes have threatened the goals of French interveners in Mali as well as in the Central African Republic and Chad. Sectarian conflicts driven in part by communal disputes similarly challenged the United States military in Afghanistan and Iraq. Compared to these interveners, UN peacekeepers differ in important ways that make them seem relatively more impartial and ultimately more effective. Yet the components of my theory related to impartiality are not necessarily specific to the UN. For example, local ethnic groups may perceive other multilateral organizations like the EU as relatively impartial as well. African regional organizations like ECOWAS have the additional benefit of excluding troops from former colonizers. Whether such interventions are as effective as the UN remains an open question and one I view as a promising avenue for future research on conflict. 


\section{References}

Anderlini, Sanam Naraghi. 2017. "UN Peacekeepers' Sexual Assault Problem: How to End It Once and for All." Foreign Affairs .

Arjona, Ana. 2016. "Institutions, Civilian Resistance, and Wartime Social Order: A Processdriven Natural Experiment in the Colombian Civil War." Latin American Politics and Society 58(3):99-122.

Autesserre, Severine. 2010. The Trouble with the Congo: Local Violence and the Failure of International Peacebuilding. New York, NY: Cambridge University Press.

Autesserre, Severine. 2015. Peaceland: Conflict Resolution and the Everyday Politics of International Intervention. Cambridge University Press.

Balcells, Laia. 2017. Rivalry and Revenge. Cambridge University Press.

Baldwin, Kate. 2016. The Paradox of Traditional Chiefs in Democratic Africa. Cambridge University Press.

Bauer, Michal, Christopher Blattman, Julie Chytilová, Joseph Henrich, Edward Miguel and Tamar Mitts. 2016. Can War Foster Cooperation? Working Paper 22312 National Bureau of Economic Research.

URL: http://www.nber.org/papers/w22312

Beath, Andrew, Fotini Christia and Ruben Enikolopov. 2013. "Empowering Women through Development Aid: Evidence from a Field Experiment in Afghanistan." The American Political Science Review 107(03):540-557.

Benson, Michelle and Jacob D Kathman. 2014. "United Nations Bias and Force Commitments in Civil Conflicts." The Journal of Politics 76(02):350-363.

Betts, Richard K. 1994. "The Delusion of Impartial Intervention." Foreign Affairs 73:20.

Blair, Robert A. 2019. "International Intervention and the Rule of Law after Civil War: Evidence from Liberia." International Organization 73(2):365-398.

Blair, Robert A. 2020a. Peacekeeping, Policing, and the Rule of Law after Civil War. Cambridge University Press.

Blair, Robert A. 2020b. "UN Peacekeeping and the Rule of Law." American Political Science Review pp. 1-18.

Blair, Robert, Jessica Di Salvatore and Hannah Smidt. 2020. "When Do UN Peacekeeping Operations Implement Their Mandates?" Available at SSRN .

Boone, Catherine. 2014. Property and political order in Africa: Land rights and the structure of politics. Cambridge University Press. 
Bove, Vincenzo and Andrea Ruggeri. 2015. "Kinds of Blue: Diversity in UN Peacekeeping Missions and Civilian Protection." British Journal of Political Science pp. 1-20.

Bove, Vincenzo and Andrea Ruggeri. 2019. "Peacekeeping effectiveness and blue helmets' distance from locals." Journal of Conflict Resolution 63(7):1630-1655.

Bove, Vincenzo, Chiara Ruffa and Andrea Ruggeri. 2020. Composing Peace: Mission Composition in UN Peacekeeping. Oxford University Press.

Bove, Vincenzo, Jessica Di Salvatore and Leandro Elia. 2021. "UN Peacekeeping and Households' Well-Being in Civil Wars." American Journal of Political Science.

Brown, David. 1983. "Sieges and Scapegoats: the politics of pluralism in Ghana and Togo." The Journal of Modern African Studies 21(3):431-460.

Bush, Sarah Sunn and Lauren Prather. 2018. "Who's There? Election Observer Identity and the Local Credibility of Elections." International Organization pp. 1-34.

Carnegie, Allison and Christoph Mikulaschek. 2020. "The promise of peacekeeping: protecting civilians in civil wars." International Organization 74(4):810-832.

Carter, David B and Curtis S Signorino. 2010. "Back to the future: Modeling time dependence in binary data." Political Analysis 18(3):271-292.

Carter, Kate M and Scott Straus. 2019. Changing Patterns of Political Violence in SubSaharan Africa. In Oxford Research Encyclopedia of Politics.

Conrad, David C. and Djanka Tassey Conde. 2004. Sunjata: A West African Epic of the Mande Peoples. Hackett.

Creevey, Lucy, Paul Ngomo and Richard Vengroff. 2005. "Party politics and different paths to democratic transitions: a comparison of Benin and Senegal." Party politics 11(4):471493.

Di Salvatore, Jessica. 2019. "Peacekeepers against Criminal Violence-Unintended Effects of Peacekeeping Operations?" American Journal of Political Science.

Diallo, O. A. 2017. "Ethnic clashes, jihad, and insecurity in central Mali." Peace review $29(3): 299-306$.

Diallo, Tiemoko and Adama Diarra. 2016. "Five U.N. peackeepers killed by truck bomb, mortar fire in Mali." Reuters .

Donnay, Karsten, Eric T Dunford, Erin C McGrath, David Backer and David E Cunningham. 2019. "Integrating conflict event data." Journal of Conflict Resolution 63(5):1337-1364.

Doyle, Michael and Nicholas Sambanis. 2006. Making War and Building Peace: United Nations Peace Operations. Princeton, NJ: Princeton University Press. 
Dumo, Denis. 2020. "South Sudan death toll in disarmament fighting rises, UN sends peacekeepers." Reuters .

URL: https://www.reuters.com/article/us-southsudan-unrest-idUSKCN25A1VB

Eck, Kristine. 2012. "In data we trust? A comparison of UCDP GED and ACLED conflict events datasets." Cooperation and Conflict 47(1):124-141.

Fearon, James and David D Laitin. 2003. "Ethnicity, Insurgency, and Civil War." American Political Science Review 97.

Fjelde, Hanne, Lisa Hultman and Desirée Nilsson. 2019. "Protection through Presence: UN Peacekeeping and the Costs of Targeting Civilians." International Organization 73(1).

Fortna, Virginia Page. 2008. Does Peacekeeping Work? Shaping Belligerents Choices after Civil War. Princeton University Press.

Gaston, EL and Lillian Dang. 2015. "Addressing land conflict in Afghanistan.".

Gillier, Marin. 2015. "La Coopération Dans Le Sahel: Une Approache Globale.”.

Gordon, Grant M and Lauren E Young. 2017. "Cooperation, information, and keeping the peace: Civilian engagement with peacekeepers in Haiti." Journal of Peace Research $54(1): 64-79$.

Group, IC. 2016. Central Mali: An Uprising in the Making? Brussels, Belgium: International Crisis Group.

Howard, Lise Morjé. 2008. UN Peacekeeping in Civil Wars. Cambridge University Press.

Howard, Lise Morjé. 2019. Power in Peacekeeping. Cambridge University Press.

Hultman, Lisa, Jacob D Kathman and Megan Shannon. 2020. Peacekeeping in the Midst of War. Oxford University Press.

Human Rights Watch. 2016. Abuses Spread South: Islamist Armed Groups' Atrocities, Army Responses Generate Fear. Technical report.

Human Rights Watch. 2017. Mali: Spate of Killings by Armed Groups. Technical report.

Hunnicutt, Patrick and William G. Nomikos. 2020. "Nationality, Gender, and Deployments at the Local Level: Introducing the RADPKO Dataset." International Peacekeeping $27(4): 645-672$.

Hunnicutt, Patrick, William G. Nomikos and Rob Williams. 2020. "Non-Combatants or Counter-Insurgents? The Strategic Logic of Violence against UN Peacekeeping.".

Imai, Kosuke, Luke Keele, Dustin Tingley and Teppei Yamamoto. 2011. "Unpacking the black box of causality: Learning about causal mechanisms from experimental and observational studies." American Political Science Review 105(4):765-789. 
Imperato, P. J. and G. H. Imperato. 2008. Historical dictionary of Mali. ScarecrowPress.

Jones, William I. 1972. "The Mise and Demise of Socialist Institutions in Rural Mali." Geneve-Afrique 11:19-44.

Kahler, Miles. 1992. "Multilateralism with small and large numbers." International Organization pp. 681-708.

Kaplan, Oliver. 2017. Resisting War: How Communities Protect Themselves. Cambridge University Press.

Karim, Sabrina and Kyle Beardsley. 2017. Equal Opportunity Peacekeeping: Women, Peace, and Security in Post-Conflict States. Oxford University Press.

Kelmendi, Pellumb and Andrew Radin. 2016. "UNsatisfied? Public Support for Postconflict International Missions." Journal of Conflict Resolution .

Krause, Jana. 2018. Resilient Communities: Non-Violence and Civilian Agency in Communal War. Cambridge University Press.

Krause, Jana. 2019. "Stabilization and local conflicts: Communal and civil war in South Sudan." Ethnopolitics 18(5):478-493.

Kydd, Andrew H. 2010. "Rationalist Approaches to Conflict Prevention and Resolution." Annu. Rev. Polit. Sci. 13(1):101-121.

LaFree, Gary and Laura Dugan. 2007. "Introducing the Global Terrorism Database." Terrorism and Political Violence 19(2):181-204.

Lake, David A. 2016. The statebuilder's dilemma: on the limits of foreign intervention. Cornell University Press.

Lyall, Jason, Graeme Blair and Kosuke Imai. 2013. "Explaining Support for Combatants during Wartime: A Survey Experiment in Afghanistan." American Political Science Review 107(04):679-705.

Lyall, Jason, Yang-Yang Zhou and Kosuke Imai. 2020. "Can economic assistance shape combatant support in wartime? Experimental evidence from Afghanistan." American Political Science Review 114(1):126-143.

Marijan, Branka. 2019. "Canada's reluctant participation in peacekeeping in Mali: What it reveals." Project Ploughshares .

Martin, Lisa L. 1992. "Interests, power, and multilateralism." International Organization pp. $765-792$.

Matanock, Aila M. 2017. Electing Peace: From Civil Conflict to Political Participation. Cambridge University Press. 
Mikulaschek, Christoph. 2017. "The Power of the Weak: How Informal Power-Sharing Shapes the Work of the UN Security Council." Working Paper .

Mousa, Salma. 2020. "Building social cohesion between Christians and Muslims through soccer in post-ISIS Iraq." Science 369(6505):866-870.

Murtazashvili, Jennifer Brick. 2016. Informal order and the state in Afghanistan. Cambridge University Press.

Nomikos, William G. 2021. "Peacekeeping and the Enforcement of Intergroup Cooperation: Evidence from Mali." Journal of Politics (forthcoming).

Pezard, Stephanie and Michael Shurkin. 2015. Achieving Peace in Northern Mali: Past Agreements, Local Conflicts, and the Prospects for a Durable Settlement. RAND Corporation.

Posner, Daniel N. 2005. Institutions and Ethnic Politics in Africa. Cambridge University Press.

Raleigh, Clionadh, Andrew Linke, Håvard Hegre and Joakim Karlsen. 2010. "Introducing ACLED: an armed conflict location and event dataset: special data feature." Journal of peace research 47(5):651-660.

Rhoads, Emily Paddon. 2016. Taking sides in peacekeeping: impartiality and the future of the United Nations. Oxford University Press.

Ruggeri, Andrea, Han Dorussen and Theodora-Ismene Gizelis. 2017. "Winning the peace locally: UN peacekeeping and local conflict." International organization 71(1):163-185.

Ruggeri, Andrea, Han Dorussen and Theodora-Ismene Gizelis. 2018. "On the frontline every day? Subnational deployment of United Nations peacekeepers." British Journal of Political Science 48(4):1005-1025.

Salehyan, Idean, Cullen S Hendrix, Jesse Hamner, Christina Case, Christopher Linebarger, Emily Stull and Jennifer Williams. 2012. "Social conflict in Africa: A new database." International Interactions 38(4):503-511.

Sambanis, Nicholas, Jonah Schulhofer-Wohl and Moses Shayo. 2012. "Parochialism as a Central Challenge in Counterinsurgency." Science 336(6083):805-808.

Seely, Jennifer C and Samuel Decalo. 2021. Historical Dictionary of Togo. Rowman \& Littlefield Publishers.

Sexton, Renard. 2016. "Aid as a Tool against Insurgency: Evidence from Contested and Controlled Territory in Afghanistan." American Political Science Review 110(4):731-749.

Smidt, Hannah M. 2019. "United Nations peacekeeping locally: enabling conflict resolution, reducing communal violence." Journal of Conflict Resolution . 
Sundberg, Ralph, Kristine Eck and Joakim Kreutz. 2012. "Introducing the UCDP Non-State Conflict Dataset." Journal of Peace Research 49(2):351-362.

Talentino, Andrea Kathryn. 2007. "Perceptions of peacebuilding: The dynamic of imposer and imposed upon." International Studies Perspectives 8(2):152-171.

Tambiah, Stanley J. 1989. "Ethnic conflict in the world today." American ethnologist 16(2):335-349.

Tull, D. M. 2019. "Rebuilding Mali's army: the dissonant relationship between Mali andits international partners." International Affairs 95(2):405-422.

UN News. 2020. "UNMISS peacekeepers begin patrols to deter further violence in conflictaffected Tonj.".

URL: https://peacekeeping.un.org/en/unmiss-peacekeepers-begin-patrols-to-deter-furtherviolence-conflict-affected-tonj

Villa, Danielle. n.d. "Biased Bases? Host Government Influence on Subnational United Nations Peacekeeper Deployment.".

Walter, Barbara F, Lise Morje Howard and V Page Fortna. 2019. "The Extraordinary Relationship between Peacekeeping and Peace." British Journal of Political Science pp. 118.

Wilfahrt, Martha. 2018. "The politics of local government performance: Elite cohesion and cross-village constraints in decentralized Senegal." World Development 103:149-161.

Wing, Susanna. 2013. "Making Sense of Mali." Foreign Affairs .

Wood, Elisabeth J. 2006. "Variation in Sexual Violence during War." Politics and Society $34(3): 307-342$. 